\title{
$\begin{array}{ll}\text { Research Square } & \text { Preprints are preliminary reports that have not undergone peer review. } \\ \text { They should not be considered conclusive, used to inform clinical practice, }\end{array}$ or referenced by the media as validated information. \\ Scaling debt for nature swaps - which nature, how much debt and who pays?
}

\section{Christoph Nedopil}

Fudan University, Shanghai https://orcid.org/0000-0001-9408-4935

\section{Mengdi Yue}

International Institute of Green Finance, Central University of Finance and Economics, Beijing

Alice Hughes ( $\square$ ach_conservation2@hotmail.com )

University of Hong Kong https://orcid.org/0000-0002-0675-7552

\section{Article}

Keywords:

Posted Date: March 1st, 2022

DOI: https://doi.org/10.21203/rs.3.rs-1358929/v1

License: (1) This work is licensed under a Creative Commons Attribution 4.0 International License.

Read Full License 
Scaling debt for nature swaps - which nature, how much debt and who pays?

Christoph Nedopil ${ }^{1}$, Mengdi Yue ${ }^{2}$, Alice C. Hughes*3

${ }^{1}$ Fanhai International School of Finance, Fudan University, Shanghai

${ }^{2}$ International Institute of Green Finance, Central University of Finance and Economics, Beijing

${ }^{3}$ School of Biological Sciences, University of Hong Kong.

*ach_conservation2@hotmail.com

\begin{abstract}
With the upcoming launch of the post-2020 global biodiversity framework and an accelerating sovereign debt crisis in many emerging economies related to COVID19, we analyze how the resurgent call for debt-for-nature swaps could conserve currently unprotected biodiversity priority-areas for six biomes and support debt restructuring in 67 countries under the World Bank's debt service suspension initiative. Using novel methods and data, we find that the 67 countries hold over $22 \%$ of global priority-areas, $82.96 \%$ of which is unprotected. However, even when using conservative cost estimates, protecting $100 \%$ of those currently unprotected areas would only convert $0.1 \%$ of public debt for 35 of the 67 countries and would not significantly reduce debt levels. Applying DNS in the remaining countries would allow the protection of $11-13 \%$ of the Earth's currently unprotected priority areas and would require particularly China to engage in swapping between USD2.8 and 5.5 billion in debt.
\end{abstract}

One-Sentence Summary: We develop a framework for efficient application of debt-fornature swaps to maximize biodiversity conservation. 


\section{Main Text:}

With the upcoming launch of the post-2020 global biodiversity framework, we have an opportunity to improve on past frameworks, and bridge the gaps which may have hindered their success (1). One reason for the previous lack of success was insufficient finance for biodiversity $(2,3)$. Only Aichi target 11 came close to success, as protected areas are a key tool for biodiversity conservation, yet selection of areas for protection may be due to historical reasons, or lack of other pressures on land, and may not represent optimal areas for biodiversity (4). Understanding how to make most efficient use of resources represents a perpetual challenge in conservation, representing a compromise between human needs and maintenance of biodiversity as well as ecosystem service provision. Identifying areas with the potential to maintain high diversity, whilst minimizing the loss of productive land can represent a low-cost approach to maximizing conservation gains whilst minimizing economic and social impacts.

Debt-for-nature swaps (DNS) are a financial tool initially developed in the 1980s to exchange sovereign debt for conserving or restoring nature and thus provide an instrument to finance nature protection. DNS have regained prominence in the aftermath of COVID19 (5) driven by two parallel developments: rising national public debt leading to risk of debt default particularly in emerging economies on the one hand, and, accelerated by the debt crisis, a further decrease in financial resources for conservation whilst stimulating the need for potentially unsustainable economic growth on the other. The debt crisis has led to the establishment of the debt-service suspension initiative (DSSI) of the G20 and the Common Framework (6) that has provided a temporary suspension of debt-service payments for up to for 73 eligible countries in the whose debt levels became unsustainable during the COVID-19 pandemic since May 2020. By January 2022, the DSSI had delivered US\$10.3 billion in relief to 40 countries, highlighting the value of such an approach as a tool for conservation, yet mechanisms to maximise effectiveness of DNS for conservation has rarely been discussed.

DNS have been discussed at various points - including by the European Union to be applied in the current crisis (7). DNS could theoretically ameliorate both problems: reduce debt burdens, particularly in emerging economies with high external public debt, and direct funds to conservation or restoration in these countries $(8,9)$. Yet translating this framework into action and applying it to maximize its effect on nature protection and debt reduction is complex, especially since scalability of this approach is hampered by debt negotiations between public and private debt holders, national interests and support of debtor countries (5), and idiosyncratic natural endowments (10). As a consequence, DNS have been successfully executed in specific countries in the aftermath of COVID19, e.g., in Belize in 2021 (11). At the same time, the World Bank and IMF, two of the largest creditors in emerging economies, had evaluated an inclusion of DNS to restructure their debt in May 2021 (12), but stalled progress due to lack of DNS scalability (13).

In this study, we evaluate how DNS could be applied to efficiently maximize national conservation and minimize public debt, and regard further factors like minimizing economic harm to creditors and ideally enhancing social and economic development opportunities. Our evaluation focuses on identifying "which nature" could most efficiently protect biodiversity, while minimizing economic and social disruption, "how much" it would cost to acquire and manage nature, and "whose debt" - that is which creditors - to engage for debt swaps.

To explore how DNS could effectively be applied we identify biodiversity priorityareas within 15 biomes nestled within five major ecotones (forests, grasslands, deserts, 
mangroves and freshwater). These priority areas are identified on the basis of the potential to host high species richness, and cross-validated across other metrics of richness. Given the low level of modification in these areas at present, protection of these areas is expected to be less socially disruptive but potentially add jobs in protected area management and tourism, but as they are currently not under intensive use will have little or no immediate negative economic impacts. We calculate the global share of biodiversity priority-areas and the degree of protection of these biomes in 67 of the 73 countries DSSI which had sufficient data available (6) (i.e., "which nature"). We then calculate the acquisition and management cost for priorityareas using best available data (i.e., "how much debt") using different scenarios and thresholds that allow for meaningful debt reduction; and we identify biodiversity targets to be swapped with different creditors based on World Bank debt data (i.e., "whose debt").

We focus specifically on DNS, understanding that other debt restructuring instruments that include nature conservation are also being evaluated as useful tools for conservation, such as Nature performance bonds/securities. However, our focus on DNS is driven by three considerations: first, they are more relevant for debtor countries in debt distress without easy access to capital markets to raise new funds, while for countries without debt distress or default, nature performance securities might be more applicable (see also the case of Belize in December 2021(11)). Secondly, compared to nature performance bonds that offer debtor countries a choice to accelerate economic development over environmental protection in exchange for higher interest rates on the debt instrument, DNS have a more contractual conservation agreement. Thirdly, while nature performance bonds need to prove nature protection ex-post at the risk of incurring high transaction cost, DNS require ex-ante evaluation and agreements on the nature swap and thus enable more effective conservation (14), though further measures are needed to counteract the multifaceted drivers of species decline even following the identification and protection of key areas (15). Both mechanisms can, nevertheless, be combined at the debt restructuring and nature protection nexus.

This article thus identifies biodiversity priorities on a national basis that would benefit from DNS. We focus largely on terrestrial ecosystems as these largely face direct threats due to damage and loss that is not from displaced activities such as chemical or climate related issues, and includes activities which may most effectively be targeted by local spatial conservation approaches (deforestation (9), overgrazing (16), rapid loss of mangroves (17-19) and river fragmentation (20)). Furthermore the pressure on these areas, given the postpandemic urgency of economic growth, may increase further, underscoring the urgency in effective modes of protection before these areas are modified. We focus on intact but unprotected areas, as these areas are most likely to maintain original species, require little if any restoration and are often not under direct private management and use, but under government management making them easier to swap for sovereign debt. In addition, protecting intact unprotected yet threatened areas, DNS can reduce habitat loss and degradation prevalent in much of the world, while providing a more cost-effective solution than restoring already degraded land. The focus on intact land also reduces the risk of displacing economic activity, reducing the economic impacts as well as the costs. Rather, as many countries struggle to recover economically from the Covid-19 pandemic providing alternate jobs and livelihood provision is crucial for economic recovery, and investment in protection and the development of ecotourism can provide such an opportunity.

Identifying and protecting areas at risk of development is also crucial, for example with the growth of roads through initiatives such as the belt and road may spur development of 
formerly inaccessible areas, and a failure to proactively protect areas in the proximity of new transport routes may otherwise result in their modification and loss due to development, or unsustainable harvest of natural products. Thus, targeting vulnerable biodiverse areas for protection could effectively help deliver the goals of the post-2020 global biodiversity framework and provide an efficient mechanism for prioritization to develop and deliver future goals.

We focused on terrestrial areas, as many biodiversity threats in marine areas are displaced from elsewhere, and some such as pollution, bleaching and acidification cannot be easily countered through spatial efforts in the same way land degradation can (21), and more complex mechanisms may be needed. Thus whilst marine systems are threatened, managing fishing sustainably, reducing pollution and managing climate change as part of a complex suite of mitigation strategies may be more effective at reducing marine diversity losses, especially as protection may be undermined by activities outside the protected area in marine systems (21). Accordingly, we specify recommendations how to effectively and efficiently use DNS to establish and manage currently unprotected terrestrial priority-areas of major biomes, which would enable a more representative protection of these key, potentially vulnerable systems, though conditions to monitor performance would be needed to ensure new protected areas were effective.

In our analyses, we expand on the approaches detailed by Simmons et al. (5), by developing a more targeted framework for identifying biodiversity priorities and including creditors beyond China, while also avoiding making assumptions on the effect of local governance on the applicability of DNS application - for three reasons: first, governance in most DSSI countries is below global averages (22) and finding a cut-off point for quality of governance seems both arbitrary and would exclude too many DSSI countries from DNS from the outset; second, successful cases of DNS have been implemented in countries with weaker governance, such as Belize and Colombia; third, even in countries with good governance, conservation efforts fail due to ineffective management (3). Accordingly, we aim to provide data and a framework on where DNS could be applied effectively to protect nature and at what cost for whom, recognizing that effective management is a prerequisite for protected areas under any quality of institutional governance (23).

\section{Swapping debt for nature - from idea to implementation}

DNS were first introduced in 1984 in response to the deteriorating tropical rainforests and mounting debt obligations in developing countries (24). Through a DNS, the debtor country's debt stock is reduced in exchange for commitments of the debtor government to protect nature (25). The first debt-for-nature agreement was signed in 1987 between Bolivia and Conservation International (CI), in which CI purchased USD650,000 of Bolivia's foreign debt in the secondary market at a discounted price of USD100,000. In exchange, the Bolivian government set aside 3.7 million acres in three conservation areas (26). Since then, DNS have been applied in over 30 countries across all continents (24). From 1987 to 2015, the value of debt restructured under DNS agreements surpassed US $\$ 2.6$ billion, resulting in about US $\$ 1.2$ billion of transfers to conservation projects (25). The DNS in the Seychelles in 2018 was worth more than $1.5 \%$ of debtor country's GDP and led to the protection of $30 \%$ of the Seychelles marine ecosystem (27). The 2021 DNS in Belize created a conservation fund worth $10 \%$ of Belize's GDP, and set aside $30 \%$ of its ocean for conservation, while involving exclusively private creditors (11). Of all DNS agreements from 1987 to 2015, over 93\% were DNS involving public creditors (25). 
By value, most DNS were in Latin American countries with Mexico signing 12 DNS deals with the US from 1991-1998. Yet huge potential exists in other developing countries, which hold a disproportionate amount of global biodiversity, but in many cases failed to meet Aichi Target 11 of $17 \%$ protected area coverage.

After the debt restructurings by the Paris Club (28) - (a group of officials from mostly developed countries with the responsibility to coordinate solutions for countries with sovereign debt payment issues) - in the 1980s and 1990s, coupled with a stable global economy, fewer sovereign debt crises surfaced and fewer DNS were applied in the 2000s. Since 2020, sovereign debt issues have accelerated due to COVID19, causing some emerging countries (e.g., Zambia (29)) to default on their debt and put more at risk of debt default (30). Simultaneously, accelerating environmental destruction (31) and the accompanying need to mobilize billions to finance nature protection (32) has led to a resurgence of calls to apply DNS (33), including from large creditor regions, such as in September 2021 from the European Commission (7).

\section{Mechanics of a debt-for-nature swap}

The specific mechanics of a DNS are idiosyncratic for each DNS, yet all exhibit common principles and can be adapted as effective conservation tools. If a loan agreement between debtor and creditor government(s) is at risk of default, negotiations can lead to a decision to swap debt for nature: creditors sell outstanding debt at a discount of up to $100 \%$ to an environmental trust fund. The trust fund is funded by public and private sponsors (NGOs, donor countries, private investors etc.) and might include a debt guarantee obtained through multilateral or government instruments, allowing it to reduce risks of the debt and thus interest rates payable to the remaining or new creditors. Together with the debtor government, the trust fund and any other relevant governance body evaluate and designate new protected areas (PAs) in the debtor country. Thus, as core part of the debt swap from original creditors to the trust fund, the debtor government agrees to designate new PAs, and receives a reduced interest rate on the swapped debt, which now needs to be paid to the environmental trust fund instead of the original creditors. Depending on the arrangement, the trust fund might pay some of the interest payments received to its sponsors, while setting aside a relevant amount to consistently pay, e.g., for PA management costs (Fig. 1).

Due to continued interest payments by the debtor country, DNS, contrary to other debt restructuring methods (in comparison to, debt forgiveness etc) reduce potential moral hazard with the debtor country to become over-exposed to debt again at little economic cost, while ensuring local benefits (in comparison to, e.g., debt-for-resources swaps) (34) and allow for higher permanence through provision of PA management cost. A DNS can therefore provide a financially viable mechanism to reduce debt, and conserve biodiversity, in line with the potential post-2020 global biodiversity framework.

Efficient application of DNS requires addressing several obstacles, including identification of relevant nature to swap (i.e., "which nature"), evaluating the cost for this nature to understand whether DNS is scalable to effectively reduce debt (i.e., "how much debt"), and which creditors to engage (i.e., "whose debt"). Other obstacles to address include social aspects, for example job creation and social inclusion in the design of the DNS, legal issues with restructuring the debt, or governance issues for implementing conservation. By making the information of "which nature", "how much debt" and "whose debt" accessible in a rigorous framework, we aim to evaluate the potentials and scalability of DNS, while also reducing information cost for potential DNS sponsors in identifying relevant nature and 
relevant countries. We further applied a DNS design to maximize job creation and reduce the necessity to impact existing livelihoods.

\section{Optimising debt-for-nature swaps}

\section{Which nature}

Determining priority-areas for conservation presents a challenge, as there are many alternatives on how they can be identified, and selecting appropriate indices is a continued topic of debate (35). All approaches have inherent compromises, yet developing metrics to identify potential biodiversity hotspots in the absence of accurate data for many regions means that measures should identify potential hotspots without the risk of confounding issues due to data quality. Furthermore the need to stem continued loss of intact and high diversity will be paramount to achieving future conservation targets (36). Here we set to identify areas which still retain diversity (which is most efficient both on cost, and species retention, as well as not contravening local access rights), but due to rapid rates of deforestation, grazing and other forms of degradation, are likely to be lost (and converted into economically productive land) without intervention. Rates of habitat loss remain high across many global biodiversity hotspots. Ensuring rates of loss are stemmed is paramount to reducing the rate of global biodiversity loss, before considering restoration of areas which have already lost much of their biodiversity.

Species richness indices are frequently used to provide a metric of biological diversity (37-40), despite many of these patterns resulting primarily from common species (41). Yet the quality of available global biodiversity data records of species occurrence are spatially or taxonomically biased (42). This makes comparisons between regions or taxa challenging or impossible (43). Identifying areas for priorities needs to overcome spatial biases in commonly used datasets, to ensure hotspots are captured, including areas with insufficient data to assess their species composition. To circumvent these issues, we identified areas with low/no disturbance (based on an updated version of the human footprint map (44)) and then identified the most productive parts of 15 biomes based on productivity data. Biomes were used as ensuring representative protection across taxa and biomes is also critical (36). Using productivity as a surrogate of available energy for the ecosystem, and therefore diversity, removes spatial errors due to uneven data collection and digitisation efforts $(42,43)$. By identifying the most productive parts of each intact biome, we highlight the areas with the greatest ability to support biological diversity, as productivity has been shown to be a correlate for species richness in a number of studies (45-47). To assess the appropriate productivity metric, we compared the overlap with hotspots identified using IUCN and birdlife data for several different productivity metrics. This comparison assesses if hotspots are retained to ensure known hotspots are captured, but areas missed by these datasets (i.e., due to political borders) are encompassed by using an index that is standardized and representative across the planet, as it does not require human decisions compared to species-based indices. Once the most potentially diverse parts and the percentage of priority-areas falling into each country have been identified, the relevant percentages of five major biomes (forest, grassland/savanna, desert, riparian and freshwater, and mangrove) were calculated. To ensure our targets consistently captured known sites of diversity, we compared our results to existing maps of richness for four vertebrate and one invertebrate taxa, whilst avoiding potential biases inherent in many of these maps, thus we aimed to show a high degree of overlap with areas identified 
in those datasets as diverse, but to circumvent issues associated with political boundaries and other biases which may underestimate diversity in some regions based on such data. These potential richness maps were also used to determine which productivity was the best potential surrogate for species richness. Finally, we analyze how much of those priority-areas are currently unprotected. This analysis was first conducted at a global level, then for the 67 DSSI countries for detailed analysis.

Overall, the 67 DSSI countries host $22.31 \%$ of global biodiversity priority-areas, while only $17.03 \%$ of these priority-areas are protected (Table 1, Data S1, Fig. 2A). Notably only $47.7 \%$ of protected areas (PA) overlapped with priority-areas in these countries, highlighting the importance of protected area placement: Somalia, Liberia, Djibouti have some of the lowest percentages of national priority-areas protected at $0-0.05 \%$. Even as the area protected increases, protection of priority-areas may not if suboptimal land is protected (e.g., Haiti protects $2.17 \%$ of its land, but only $0.28 \%$ of its priority). Conversely, some countries with little overall protection protect most remaining priorities (e.g., Bangladesh protects $4.43 \%$ of land area and $76.65 \%$ of its priority-areas).

\section{Biome-specific debt-for nature swaps}

To allow for biome-specific DNS (e.g., in the interest of specific DNS sponsors), we identify priority-areas and assess their protection across biomes (see Table 1). Assessing priorities on a per-biome basis maximizes ecological representativeness, which may otherwise miss regions with low absolute diversity but unique species assemblages. We assessed the percentage of global priorities that fell into each country for each biome, as well as exploring what percentage of land, and priorities was covered by priorities or protected at a national level.

For forest priorities (based on current forest coverage), the DR Congo is hosts $6.47 \%$ of the Earth's priority forest areas (Fig. 2A-B). These areas make up 62\% of DR Congo's land area, yet protected priority-areas only make up $9 \%$ of DR Congo's area covering $15 \%$ of its forest priorities (Fig. 2). A drastic case is Papua New Guinea, which hosts $1.8 \%$ of global top priority forest areas, equating to $60 \%$ of the islands land area. Yet protected priority-areas only makeup $1.2 \%$ of the island, and $2 \%$ of national priority-areas.

For grassland priorities, Angola hosts $9.5 \%$ of global priority-areas. These priorityareas occupy $78.92 \%$ of the country's land area, of which only $4.72 \%$ are protected. Similarly, the DR Congo is a major priority for grasslands, with $9.47 \%$ of the Earth's priority grassland, of which only $9.51 \%$ are protected. For desert priorities few DSSI countries host desert priorityareas: among those, Madagascar hosts $1.9 \%$ of global desert priority-areas, of which $21.91 \%$ are protected.

For mangroves, Papua New Guinea hosts $7.41 \%$ global priority-areas. These equate to less than $0.4 \%$ of Papua New Guinea's land area. Nevertheless, only $4.42 \%$ of these mangrove priority-areas are protected. Bangladesh hosts the next greatest mangrove area, $(2.32 \%$ of global priority-areas), representing $0.4 \%$ of the country. Bangladesh protects almost all $(98.96 \%)$ of its mangroves and would thus not necessarily represent a good choice for mangrove-specific DNS. The Solomon Islands hosts $1.64 \%$ of global priority-areas, which make up less than $1.4 \%$ of the land area, of which only $5.65 \%$ are protected. For freshwater priorities the DR Congo hosts $7.02 \%$ global priority-areas, making up $9.34 \%$ of its landmass of which $17.94 \%$ are protected. This is followed by Papua New-Guinea which is home to $2.2 \%$ global freshwater priority-areas, of which $4.08 \%$ are protected. 


\section{Country specific debt-for-nature swaps}

For country-specific DNS, e.g., to maximize priority-area protection within Aichi target 11 of $17 \%$ PA coverage, knowledge of priority-areas relevant for effective protection in each country is required.

We calculate the percentages of unprotected priority-areas for each country and biome, analyzing relevant coverage we identify specific national targets for DNS to maximize national and global priority-area protection (Fig. 2B). DR-Congo has the highest priority-area, which hosted $5.2 \%$ of global surface area across all priority-areas, occupying $88 \%$ of DR Congo's land area, of which $12.69 \%$ are protected. In African countries, DNS has significant potential for grasslands. Tropical countries, like the Solomon Islands, Papua New Guinea and Madagascar, are most in need of mangrove protection. Furthermore, countries like DR Congo have seen rapid rates of deforestation, having lost $8 \%$ forest coverage since 2000 , and around $0.7 \%$ annually for the last four years (48) (Data S1).

\section{How much debt for nature?}

The 67 countries had about USD522 billion external public debt stocks at the end of 2019. Public external debt as a percentage of GDP varies greatly across the 67 countries: in 10 countries, the ratios are higher than 50\%, including Bhutan (104\%), Cabo Verde (92\%), Mozambique (73\%), Djibouti (65\%) and Mongolia (60\%), Sao Tome and Principe (58\%), Lao PDR (57\%), Mauritania (56\%), Senegal (55\%) and Zambia (51\%). For most (55/67) countries, the ratio falls between $10 \%$ and $50 \% .46 \%$ of debt held by official multilateral creditors (e.g., World Bank), $34 \%$ by official bilateral creditors (e.g., China), $13 \%$ by bondholders, and $7 \%$ by non-official creditors (Fig. 3A). Some or all of this debt could be used for DNS.

Establishing the amount of debt requires specifying the cost to establish and manage protected areas for each biome, as well as in general. This, however, is challenging: surveys on acquisition and operating cost for protected areas, as well as their ratios, vary both across and within regions and biomes by factors of 50 (49). To nevertheless estimate the cost (see details in supplemental text), we analyzed data from previous and current DNS (e.g., Seychelles), data on conservation cost (49) including more granular, albeit older, conservation cost data provided by James et al. (50). To evaluate the applicability and scalability of DNS, we adjusted the cost data based on the approach by James et al. to 2020 USD, and providing sensitivity analyses using a plus $15 \%$ and a minus $15 \%$ cost scenarios. As a result, average PA acquisition cost per $\mathrm{km}^{2}$ ranges from USD1,535 in Sub-Saharan African, to USD17,350 in the Pacific. We estimate annual operating cost at $31 \%$ of acquisition cost (51) on average, recognizing high variability depending on e.g., the frequency of patrols, type of patrol, the area size and local salaries. As for acquisition cost, we used more conservative estimates for operating cost.

Across all countries, a normalized swap with a maximum of $100 \%$ debt swapped, the total swaps would be worth USD19.4/21.6/23.5 billion. When comparing to previous estimates of conservation cost, e.g., Waldron et al. (49), we estimate the non-normalized acquisition cost for all priority-areas in the surveyed countries at USD 26.6 billion, equaling $5.06 \%$ of these countries total sovereign debt.

Looking at specific countries, in the baseline scenario, less than $0.1 \%$ of public debt would suffice to acquire all priority-areas for 35 countries, while for four countries even $100 \%$ of their public debt would not suffice to acquire unprotected priority-areas (Solomon Islands, Papua New Guinea, Guyana and Central African Republic - Fig. 3 B). In the $+15 \% /-15 \%$ scenarios (based on an assessment of the sensitivity of the normalized cost), $0.1 \%$ of public 
debt would suffice to acquire all priority areas of 32/36 countries, while similarly $100 \%$ of public debt would not suffice to acquire currently unprotected priority areas for 5/4 countries. The median in the three scenarios is $0.77 \%, 0,91 \%$ and $1.04 \%$ of public debt to acquire all priority areas. In terms of absolute value, the median value of USD 47.6, 54.5 and 64.4 million for the three scenarios is well below the value of previous debt swaps (e.g., the 2021 Belize nature conservation value is estimated USD 180 million).

This means, that on the one hand for the about half of DSSI countries only a small fraction of the outstanding debt would suffice to protect currently unprotected priority areas, while in practice this also means that for these countries DNS focused on non-protected priority areas does not scale up to effectively reduce debt. To evaluate DNS application potential with the need for scalability, we filter countries by applying a threshold of at least $2 \%$ available for DNS and maximum of $30 \%$ of debt to be swapped for unprotected PA protection based on previous swaps (e.g., the Belize DNS was worth $32.5 \%$ of the original debt). This would allow $23 / 26 / 27$ countries in the three scenarios to apply DNS effectively and would result in debt swaps worth USD 9.1/11.0/12.5 billion. For the three scenarios, the sum of these DNS would result in $11.03 \% / 13.49 \% / 13.94 \%$ protection of the Earth's currently unprotected priority areas of the Earth's currently unprotected priority areas would become newly protected, in particular in grassland, forest and freshwater biomes (see Fig. 3C).

Besides acquisition cost, PA management costs need to be covered. Part of these can be paid for through "re-routed" interest payments on original debt. Based on previous DNS, we conservatively assume a 30\% discount on the swapped debt (e.g., the 2018 Seychelles DNS had a discount of only 5.4\%) and a 3\% interest rate. This would raise USD407/454/493 million annually in the three different main scenarios, and USD193/232/262 million in the filtered scenario. If these interest payments would be used in total for PA management, they would cover only about $6.8 \%$ of assumed annual cost. The annual management cost gap would amount to USD5.5/6.2/6.7 billion in the three scenarios across all countries, and USD2.6/3.2/3.6 billion in the filtered scenarios. These costs would need to be covered through other domestic or international sources, which requires further negotiation and fund raising. Possibly, part of the annual USD100 billion global climate finance commitments to developing countries reiterated during COP26 could be utilized, where biodiversity protection has been recognized as an element of climate protection.

\section{Whose debt}

Depending on the DNS scenario and depending on the participation of multilateral institutions such as the IMF and World Bank in DNS (which currently is not possible), different creditors would have to swap different amounts of debt.

We calculate the values of creditors using both assumptions - with and without participation of multilateral financial institutions. We use the three scenarios filtered for the $2 \%$ minimum and $30 \%$ maximum threshold of debt to be swapped.

Assuming an equal participation in the DNS of all creditors, multilateral and official bilateral creditors would have to provide most of the debt for swapping in the three scenarios, particularly The World Bank (14.6\%/16.3\%/16.8\%), and China - including China's official and non-official bilateral debt $(25.4 \% / 25.7 \% / 25.8 \%)$. Private bondholders would be the third largest group to support the envisaged DNS (9.2\%/8.6\%/8.5\%) (see Fig. 4A).

Under the assumption that multilateral lenders would not participate in a DNS, the distribution of debt to be swapped shifts towards bilateral lenders (both official and 
unofficial) and bondholders. In the baseline scenario, China would have to shoulder $39.6 \%$ of the debt to be swapped worth USD5.5 billion, followed by bondholders (11.4\%, or USD1.6 billion) and the next largest bilateral lender being Japan (5.41\%, or USD0.75 billion) (see Fig. 4B).

\section{Debt-for-nature swap application}

The COVID19 crisis has provided a unique opportunity to consider applying DNS to conserve key priorities in many emerging countries. DNS allow debtor countries in debt distress to reduce their debt burdens, while simultaneously establishing protected areas. For successful application, DNS development must consider legal issues and public participation, particularly to ensure the support of local populations and improvement of livelihoods.

Yet, DNS are complex in their implementation, with a particular concern regarding scalability of DNS. Our framework evaluates the scalability of DNS across 67 of the countries under the debt service suspension initiative (DSSI) for which consistent data were available. To reduce negative social externalities of converting economically active land to priority areas, we built a new dataset of currently unprotected priority areas that have low human activity for each country for five biomes (freshwater, forest, grasslands, mangroves, and deserts). A conversion to protected areas would have little negative social impacts, but rather could provide additional jobs in PA conservation. DNS can also provide an avenue for sustainable livelihood provisions through e.g. providing jobs in conservation and furthermore through developing eco-tourism in these new PAs (e.g. Kenya's ecotourism contributes around 10\% of Kenya's GDP) (52). Accordingly, if planned well, DNS provide a "triple-win" mechanism to remove financial pressures on a country, to reduce pressures on natural resources.

By assessing the cost of acquiring these areas in three different scenarios, we find that for about half the countries a protection of all currently unprotected areas would, however, only convert less than $0.1 \%$ of their current sovereign debt and would therefore not satisfy scalability to effectively reduce debt levels. For the remaining countries, we find that DNS has a potential to swap USD12-15 billion dollars, which would allow the conversion of 11-13\% of the Earth's current unprotected priority areas into protected areas, in particular grasslands, freshwater, and deserts.

To apply these DNS, we identify most important lenders and calculate their contributions in two scenarios: with and without the participation of multilateral lenders. In all cases, China would be the most important partner for swapping their official and unofficial loans, with a possible contribution of USD2.8 billion should multilaterals fully participate and USD5.5 billion without multilateral participation. This would amount to about $2.6 \%$ or $5.0 \%$ of Chinese current loans to DSSI countries.

To pay for management of priority areas, we calculate annual cost of about USD3.4 billion, of which 93\% would have to be covered through newly raised funds (the rest could be covered through re-routed interest payment on the swapped debt). Particularly through an increasing political willingness to jointly tackle climate and biodiversity risks, as witnessed for example by including biodiversity commitments at COP26 in Glasgow, we see an opportunity to utilize parts of the annual USD100 billion climate commitment from developed to developing countries.

Overall, we see opportunities and limitations for the efficient and effective application of DNS in the DSSI countries. As a concept to alleviate debt while providing nature protection, it is, however, only applicable to about half of DSSI countries, or would require more negotiations on restoring nature in areas with higher human footprint leading to higher social 
and economic cost. The potential to apply DNS as an effective conservation tool is inarguable, yet maximizing gains requires a clearer understanding of costs, local capacity, and political willingness with creditors and debtors. Furthermore, modes of engagement to ensure metrics are meaningful indicators of biodiversity retention are required, while effective engagement to increase the social and economic benefits as well as those to biodiversity must be ensured. By focusing on countries identified in this paper, a faster application of DNS could be achieved, providing relevant lessons as effective way to enable countries to meet commitments and targets nationally, and for global conventions such as the CBD.

\section{References}

1. Secretariat of the Convention on Biological Diversity, "Global Biodiversity Outlook 5" (Montreal, 2020), (available at https://www.cbd.int/gbo/gbo5/publication/gbo-5-en.pdf).

2. A. Seidl, K. Mulungu, M. Arlaud, O. van den Heuvel, M. Riva, The effectiveness of national biodiversity investments to protect the wealth of nature. Nat Ecol Evol. 5, 530-539 (2021).

3. J. E. M. Watson, N. Dudley, D. B. Segan, M. Hockings, The performance and potential of protected areas. Nature. 515, 67-73 (2014).

4. V. M. Adams, P. Visconti, V. Graham, H. P. Possingham, Indicators keep progress honest: A call to track both the quantity and quality of protected areas. One Earth. 4, 901-906 (2021).

5. B. A. Simmons, R. Ray, H. Yang, K. P. Gallagher, China can help solve the debt and environmental crises. Science. 371, 468-470 (2021).

6. World Bank, Debt Service Suspension Initiative. World Bank (2021), (available at https://www.worldbank.org/en/topic/debt/brief/covid-19-debt-service-suspension-initiative).

7. Lazard, "Debt-for-SDGs swaps in indebted countries: The right instrument to meet the funding gap?" (European Commission, 2021).

8. A. Dibley, T. Wetzer, C. Hepburn, National COVID debts: climate change imperils countries' ability to repay. Nature. 592, 184-187 (2021).

9. J. M. Sommer, M. Restivo, J. M. Shandra, The United States, Bilateral Debt-for-Nature Swaps, and Forest Loss: A Cross-National Analysis. The Journal of Development Studies. 56, 748-764 (2020).

10. L. Zhu, A. C. Hughes, X.-Q. Zhao, L.-J. Zhou, K.-P. Ma, X.-L. Shen, S. Li, M.-Z. Liu, W.-B. Xu, J. E. M. Watson, Regional scalable priorities for national biodiversity and carbon conservation planning in Asia. Science Advances (2021), doi:10.1126/sciadv.abe4261.

11. C. Landers, N. Lee, Belize's Big Blue Debt Deal: At Last, A Scalable Model? Center For Global Development (2021), (available at https://www.cgdev.org/blog/belizes-big-blue-debt-deal-last-scalable-model). 12. A. Shalal, IMF, World Bank to unveil "green debt swaps" option by November, Georgieva says. Reuters (2021), (available at https://www.reuters.com/article/us-imf-world-bank-climate-swapsidUSKBN2BV2NU).

13. A. Shalal, IMF struggling over long-awaited "green debt swap" push as COP26 nears. Reuters (2021), (available at https://www.reuters.com/business/sustainable-business/imf-struggling-over-long-awaited-greendebt-swap-push-cop26-nears-2021-10-29/).

14. F4B-Initiative, "Recapitalising Sovereign Debt - Why Nature Performance Bonds are needed now" (Finance for Biodiversity Initiative, 2020), (available at https://a1be08a4-d8fb-4c22-9e4a-

2b2f4cb7e41d.filesusr.com/ugd/643e85_e2f3eccae35c45a8b875a974a8918922.pdf).

15. C. J. Brown, M. Bode, O. Venter, M. D. Barnes, J. McGowan, C. A. Runge, J. E. M. Watson, H. P. Possingham, Effective conservation requires clear objectives and prioritizing actions, not places or species. PNAS. 112, E4342-E4342 (2015).

16. R. Smith, in Savannas and Dry Forests: Linking People with Nature, J. Mistry, A. Berardi, Eds. (Routledge, ed. 1, 2017; https://www.taylorfrancis.com/books/9781351902090), pp. 105-127.

17. L. Goldberg, D. Lagomasino, N. Thomas, T. Fatoyinbo, Global declines in human-driven mangrove loss. Global Change Biology. 26, 5844-5855 (2020).

18. D. R. Richards, B. S. Thompson, L. Wijedasa, Quantifying net loss of global mangrove carbon stocks from 20 years of land cover change. Nat Commun. 11, 4260 (2020).

19. N. Thomas, R. Lucas, P. Bunting, A. Hardy, A. Rosenqvist, M. Simard, Distribution and drivers of global mangrove forest change, 1996-2010. PLOS ONE. 12, e0179302 (2017).

20. G. Grill, B. Lehner, A. E. Lumsdon, G. K. MacDonald, C. Zarfl, C. R. Liermann, An index-based 
framework for assessing patterns and trends in river fragmentation and flow regulation by global dams at multiple scales. Environ. Res. Lett. 10, 015001 (2015).

21. T. Agardy, G. N. di Sciara, P. Christie, Mind the gap: Addressing the shortcomings of marine protected areas through large scale marine spatial planning. Marine Policy. 35, 226-232 (2011).

22. Transparency International, 2021 Corruptions Perceptions Index - Explore the results.

Transparency.org (2021), (available at https://www.transparency.org/en/cpi/2021).

23. R. L. Pressey, P. Visconti, P. J. Ferraro, Making parks make a difference: poor alignment of policy, planning and management with protected-area impact, and ways forward. Phil. Trans. R. Soc. B. 370, 20140280 (2015).

24. P. A. Sheikh, "Debt-for-Nature Initiatives and the Tropical Forest Conservation Act: Status and Implementation" (Congressional Research Service, 2018), p. 21.

25. Debt for nature swaps. UNDP, (available at

https://www.sdfinance.undp.org/content/sdfinance/en/home/solutions/debt-for-nature-swaps.html\#mst-1).

26. P. Shabecoff, Bolivia to Protect Lands in Swap for Lower Debt. The New York Times (1987), p. 2.

27. Convention on Biological Diversity (CBD), "Seychelles Fact Sheet" (Convention on Biological

Diversity (CBD), 2016), (available at https://www.cbd.int/doc/meetings/mar/soiom-2016-01/other/soiom-201601-seychelles-01-en.pdf).

28. Club de Paris, (available at https://clubdeparis.org/).

29. E. Smith, Zambia becomes Africa's first coronavirus-era default: What happens now? CNBC (2020), (available at https://www.cnbc.com/2020/11/23/zambia-becomes-africas-first-coronavirus-era-default-whathappens-now.html).

30. S. Cevik, B. Öztürkkal, "Congation of Fear: Is the Impact of COVID-19 on Sovereign Risk Really Indiscriminate," IMF Working Paper (WP/20/263, 2020), (available at

https://www.imf.org/en/Publications/WP/Issues/2020/11/25/Contagion-of-Fear-Is-the-Impact-of-COVID-19-onSovereign-Risk-Really-Indiscriminate-49903).

31. WWF, "Living Planet Report 2020 - Bending the Curve of Biodiversity Loss" (WWF, Gland, 2020), (available at https://www.zsl.org/sites/default/files/LPR\%202020\%20Full\%20report.pdf).

32. A. Deutz, G. M. Heal, R. Niu, T. Townshend, L. Zhu, A. Delmar, A. Meghji, S. A. Sethi, J. Tobin-de la Puente, "Financing Nature: Closing the global biodiversity financing gap" (The Paulson Institute, The Nature Conservancy, and the Cornell Atkinson Center for Sustainability, 2020), (available at https://www.paulsoninstitute.org/wp-content/uploads/2020/09/CBD-Full-Report-Endorsements-.pdf).

33. United Nations, "Liquidity and Debt Solutions to INvest in the SDGs: The TIme to Act is Now" (United Nations, New York, Geneva, 2021), (available at https://www.un.org/sites/un2.un.org/files/sg_policy_brief_on_liquidity_and_debt_solutions_march_2021.pdf). 34. M. Ferry, The carrot and stick approach to debt relief: overcoming moral hazard. Journal of African Economies. 28, 252-276 (2019).

35. A. S. Kukkala, A. Moilanen, Core concepts of spatial prioritisation in systematic conservation planning. Biological Reviews. 88, 443-464 (2013).

36. S. L. Maxwell, V. Cazalis, N. Dudley, M. Hoffmann, A. S. L. Rodrigues, S. Stolton, P. Visconti, S. Woodley, N. Kingston, E. Lewis, M. Maron, B. B. N. Strassburg, A. Wenger, H. D. Jonas, O. Venter, J. E. M. Watson, Area-based conservation in the twenty-first century. Nature. 586, 217-227 (2020).

37. M. Jung, A. Arnell, X. de Lamo, S. García-Rangel, M. Lewis, J. Mark, C. Merow, L. Miles, I. Ondo, S. Pironon, C. Ravilious, M. Rivers, D. Schepaschenko, O. Tallowin, A. van Soesbergen, R. Govaerts, B. L. Boyle, B. J. Enquist, X. Feng, R. Gallagher, B. Maitner, S. Meiri, M. Mulligan, G. Ofer, U. Roll, J. O. Hanson, W. Jetz, M. Di Marco, J. McGowan, D. S. Rinnan, J. D. Sachs, M. Lesiv, V. M. Adams, S. C. Andrew, J. R. Burger, L. Hannah, P. A. Marquet, J. K. McCarthy, N. Morueta-Holme, E. A. Newman, D. S. Park, P. R. Roehrdanz, J.-C. Svenning, C. Violle, J. J. Wieringa, G. Wynne, S. Fritz, B. B. N. Strassburg, M. Obersteiner, V. Kapos, N. Burgess, G. Schmidt-Traub, P. Visconti, Areas of global importance for conserving terrestrial biodiversity, carbon and water. Nat Ecol Evol (2021), doi:10.1038/s41559-021-01528-7.

38. M. Di Marco, S. Ferrier, T. D. Harwood, A. J. Hoskins, J. E. M. Watson, Wilderness areas halve the extinction risk of terrestrial biodiversity. Nature. 573, 582-585 (2019).

39. C. N. Jenkins, K. S. Van Houtan, S. L. Pimm, J. O. Sexton, US protected lands mismatch biodiversity priorities. Proc Natl Acad Sci USA. 112, 5081-5086 (2015).

40. W. Jetz, J. M. McPherson, R. P. Guralnick, Integrating biodiversity distribution knowledge: toward a global map of life. Trends in Ecology \& Evolution. 27, 151-159 (2012).

41. W. Jetz, Geographic Range Size and Determinants of Avian Species Richness. Science. 297, 15481551 (2002). 
42. A. C. Hughes, M. C. Orr, Q. Yang, H. Qiao, Global Ecol Biogeogr, in press, doi:10.1111/geb.13304.

43. A. Hughes, M. Orr, K. Ma, M. Costello, J. Waller, P. Provoost, C. Zhu, H. Qiao, "Sampling biases shape our view of the natural world" (preprint, Preprints, 2020), , doi:10.22541/au.159419540.02222358.

44. O. Venter, E. W. Sanderson, A. Magrach, J. R. Allan, J. Beher, K. R. Jones, H. P. Possingham, W. F. Laurance, P. Wood, B. M. Fekete, M. A. Levy, J. E. M. Watson, Global terrestrial Human Footprint maps for 1993 and 2009. Sci Data. 3, 160067 (2016).

45. M. L. Hobi, M. Dubinin, C. H. Graham, N. C. Coops, M. K. Clayton, A. M. Pidgeon, V. C. Radeloff, A comparison of Dynamic Habitat Indices derived from different MODIS products as predictors of avian species richness. Remote Sensing of Environment. 195, 142-152 (2017).

46. E. M. O. Silveira, V. C. Radeloff, S. Martinuzzi, G. J. Martínez Pastur, L. O. Rivera, N. Politi, L. Lizarraga, L. S. Farwell, P. R. Elsen, A. M. Pidgeon, Spatio-temporal remotely sensed indices identify hotspots of biodiversity conservation concern. Remote Sensing of Environment. 258, 112368 (2021).

47. N. C. Coops, S. P. Kearney, D. K. Bolton, V. C. Radeloff, Remotely-sensed productivity clusters capture global biodiversity patterns. Sci Rep. 8, 16261 (2018).

48. Global Forest Watch, Democratic Republic of the Congo Deforestation Rates \& Statistics, (available at https://www.globalforestwatch.org/dashboards/country/COD/).

49. A. Waldron, V. Adams, J. Allan, A. Arnell, et.al., "Protecting 30\% of the planet for nature: costs, benefits and economic implications (Waldron Report 30 by 30)" (Cambridge University, Cambridge, 2020), (available at https://www.conservation.cam.ac.uk/files/waldron_report_30_by_30_publish.pdf).

50. A. James, K. J. Gaston, A. Balmford, Can We Afford to Conserve Biodiversity? BioScience. 51, 43-52 (2001).

51. J. J. Bohorquez, A. Dvarskas, E. K. Pikitch, Filling the Data Gap - A Pressing Need for Advancing MPA Sustainable Finance. Front. Mar. Sci. 6, 45 (2019).

52. Kenya Tourism - Total Contribution to GDP. Invest in Group, (available at https://investingroup.org/data/84/kenya-tourism-total-contribution-to-gdp/).

Acknowledgments: We acknowledge the contributions of various stakeholders in debtnegotiation and protection and are grateful for inputs by Anthony Waldron, Simon Zadek, Jeremy Eppel, Terry Townshend, Tenke Zoltan, Yao Wang, and many others to improve both methodology and data evaluation. We would also like to thank Emily Wang for editing the piece.

Funding: Provide complete funding information, including grant numbers, complete funding agency names, and recipient's initials. Each funding source should be listed in a separate paragraph.

Supported by the High-End Foreign Experts Program of Yunnan Province (Grant \#:Y9YN021B01(ACH)

Supported by the Strategic Priority Research Program of the Chinese Academy of Sciences (Grant No.XDA20050202) (ACH)

Author contributions: Each author's contribution(s) to the paper should be listed [we encourage you to follow the CRediT model]. Each CRediT role should have its own line, and there should not be any punctuation in the initials.

Examples:

Conceptualization: $\mathrm{CN}, \mathrm{ACH}$

Methodology: ACH, MDY, CN

Investigation: $\mathrm{ACH}, \mathrm{CN}, \mathrm{MDY}$ 
Visualization: $\mathrm{ACH}, \mathrm{MDY}, \mathrm{CN}$

Funding acquisition: $\mathrm{CN}, \mathrm{ACH}$

Project administration: $\mathrm{CN}, \mathrm{ACH}$

Supervision: $\mathrm{CN}, \mathrm{ACH}$

Writing - original draft: $\mathrm{ACH}, \mathrm{CN}, \mathrm{MDY}$

Writing - review \& editing: ACH, CN, MDY

Competing interests: No competing interests

Data and materials availability: All data used for analysis is cited in text as appropriate and listed in Table S8Data S5, or collated within tables as part of supplementary data. Full tabular results are available as Table Data S1. Shapefiles of percentage area within a priority and debts are available as Extended data, and high-resolution GIS files for the six biomes plus overall priorities will be made available via an online repository.

\section{Supplementary Materials}

Materials and Methods

Supplementary Text

Figures. S1

Figs. S1. Total public external debt-to-GDP ratios for 67 DSSI eligible countries by creditor type in 2019.

Tables S1-S3

Table S1. Amount of debt needed for DNS by individual creditors.

Table S2. Cost of nature.

Table S3. Assumed acquisition cost of protected areas in different regions.

Data S1 to S6

Data S1. Priorities and debt on a national basis.

Data S2. Overlaps between species richness hotspots from IUCN/Birdlife and three indicies of ecosystem productivity.

Data S3. Overlap between KBAs and priorities, and percentage forest loss since 2000 on a national basis.

Data S4. Debt to GDP of 67 countries eligible for debt for Nature swaps.

Data S5. Links to all data sources used in analysis.

Data S6. Public external debt data in 2019 for 67 DSSI eligible countries.

Fig. 1. Illustration of Debt-for-Nature Swap. Under standard loan conditions, debtor governments transfer debt service payments (including principal and interests) regularly to creditors. When the debtor government is under financial distress, a debt-for-nature swap 
could be initiated to avoid risk of default while establishing and maintaining new protected areas.

Fig. 2. Priorities for conservation. A) High resolution priorities for the different biomes across Central Africa. Note that some habitats are mixed, so may include priorities under more than one "biome" type. Top priority (T1) areas are shown in green, whereas secondlevel priorities (T2) are shown in blue. Protected priority-areas are shown as paler and grey areas are protected areas that do not cover priority-areas. B) Global priorities for biodiversity within the 67 DSSI countries. Ramp (yellow-black) shows percentage of global priority overall, pie-chart size indicates the priority as a proportion of global priority-areas (so larger pies indicate larger proportions of all global priorities, and the fractions of each colour indicate the percentage from each biome).

Fig. 3. Understanding the cost of protection. A). Public external debt and largest creditor in 67 DSSI eligible countries in 2019. The sizes of pie-charts refer to the overall public external debt-to-GDP ratios (ranging from 2-74\%), proportions of debt types are shown in pies, highlighting the degree of debt for each country and the type. Colours of the main-creditors are shown as country colour, notably many African countries are largely credited by the World Bank, followed by China. B). Cost for priority-area acquisition as $\%$ of public debt with $2 \%$ and $30 \%$ thresholds. C). Proportion of global priority-area protection under different scenarios: e.g., the 67 countries host $50.6 \%$ of global grass priority-areas. With the edge scenarios of $-/+15 \%$ cost compared to the baseline cost, $27.31 \% / 35.36 \%$ of the Earth's grassland priority areas could be conserved with the $2 \%$ minimum and $30 \%$ maximum level of debt swap. In the scenario with $+15 \%$ higher cost for PA acquisition, more countries would pass the $2 \%$ minimum threshold, making the protected area larger.

Fig. 4. Cost of debt-for-nature swaps for creditors (at baseline scenario with minimum $2 \%$ and $30 \%$ debt for nature swap. A). ... with participation by multilateral creditors B). ...without participation of multilateral creditors, and $\mathbf{C}$ ). cost per creditor in comparison in the two scenarios, showing China's contribution rising from $24.43 \%$ to $37.76 \%$.

Table 1: Overview of priorities for biodiversity; (* for grassland Zambia would be in 3rd position but as $40.01 \%$ of the priority-area is protected it has not been listed here, + for mangrove Bangladesh would be in second position, but as $99 \%$ of the priority for mangroves are already protected this would not be useful; \# for freshwater the Republic of Congo would 
be second, but with $74.8 \%$ of the priority protected we have not listed it here). Areas with under $1 \%$ of global priority for that biome have been italicized.

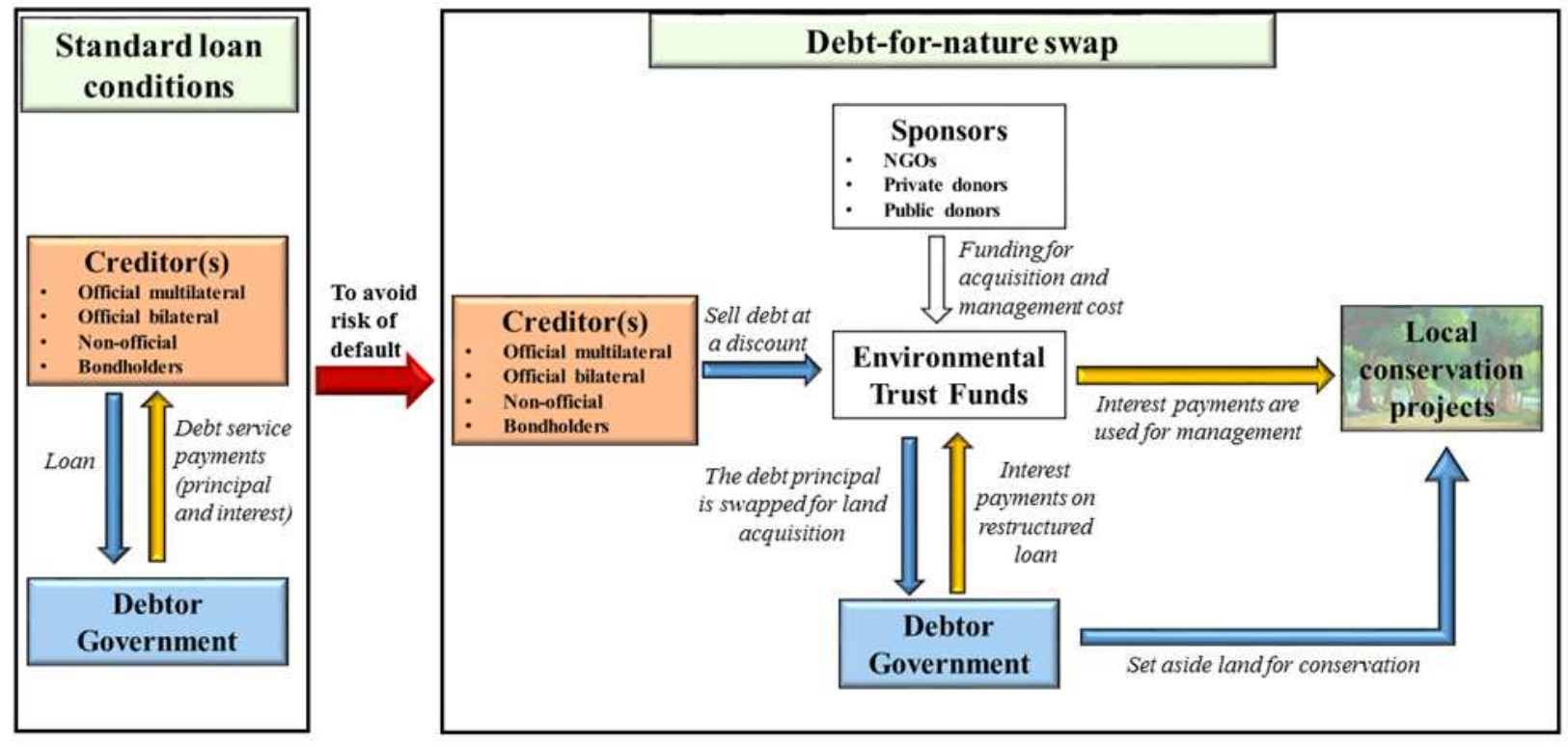

Fig 1. 


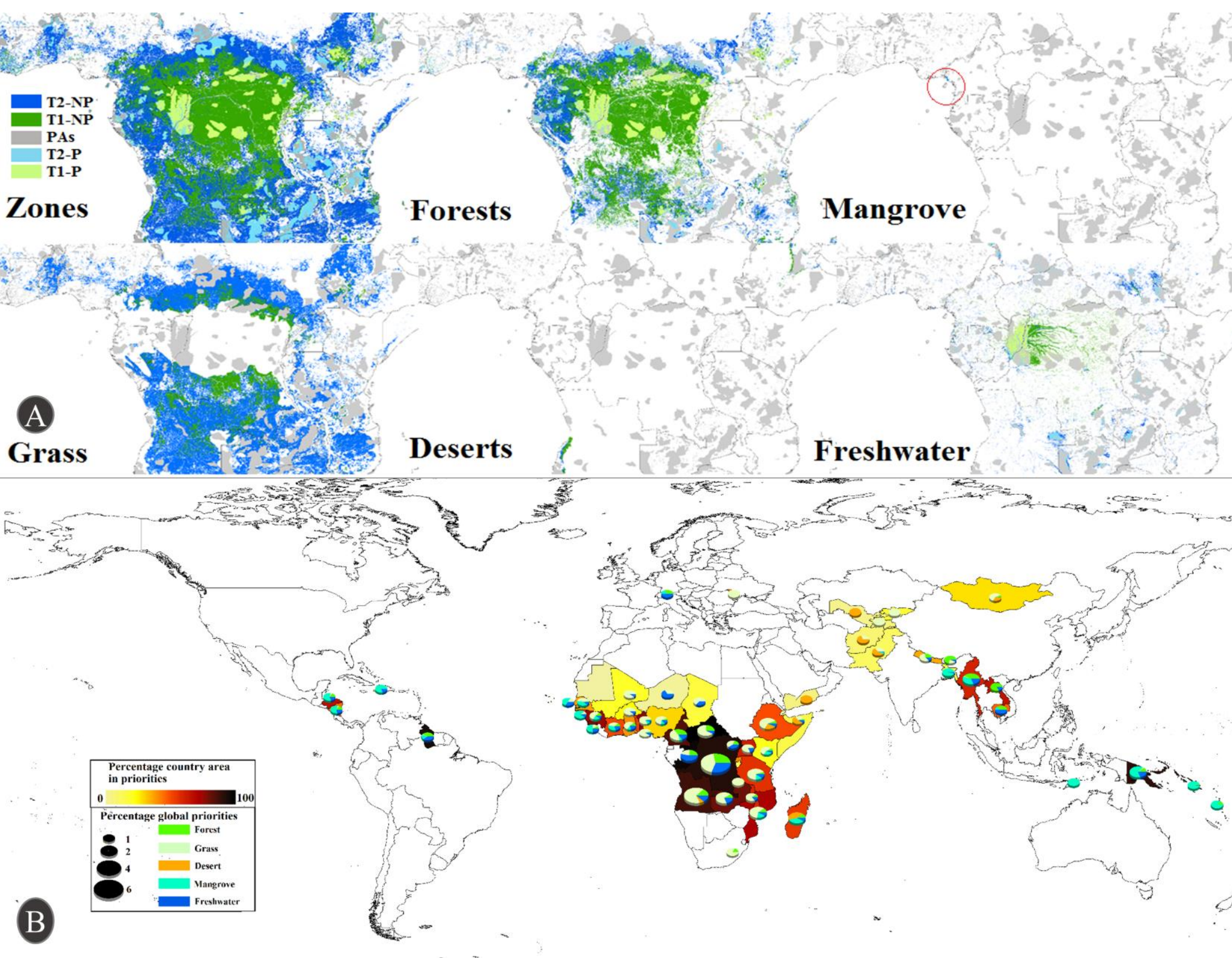

Fig.2 


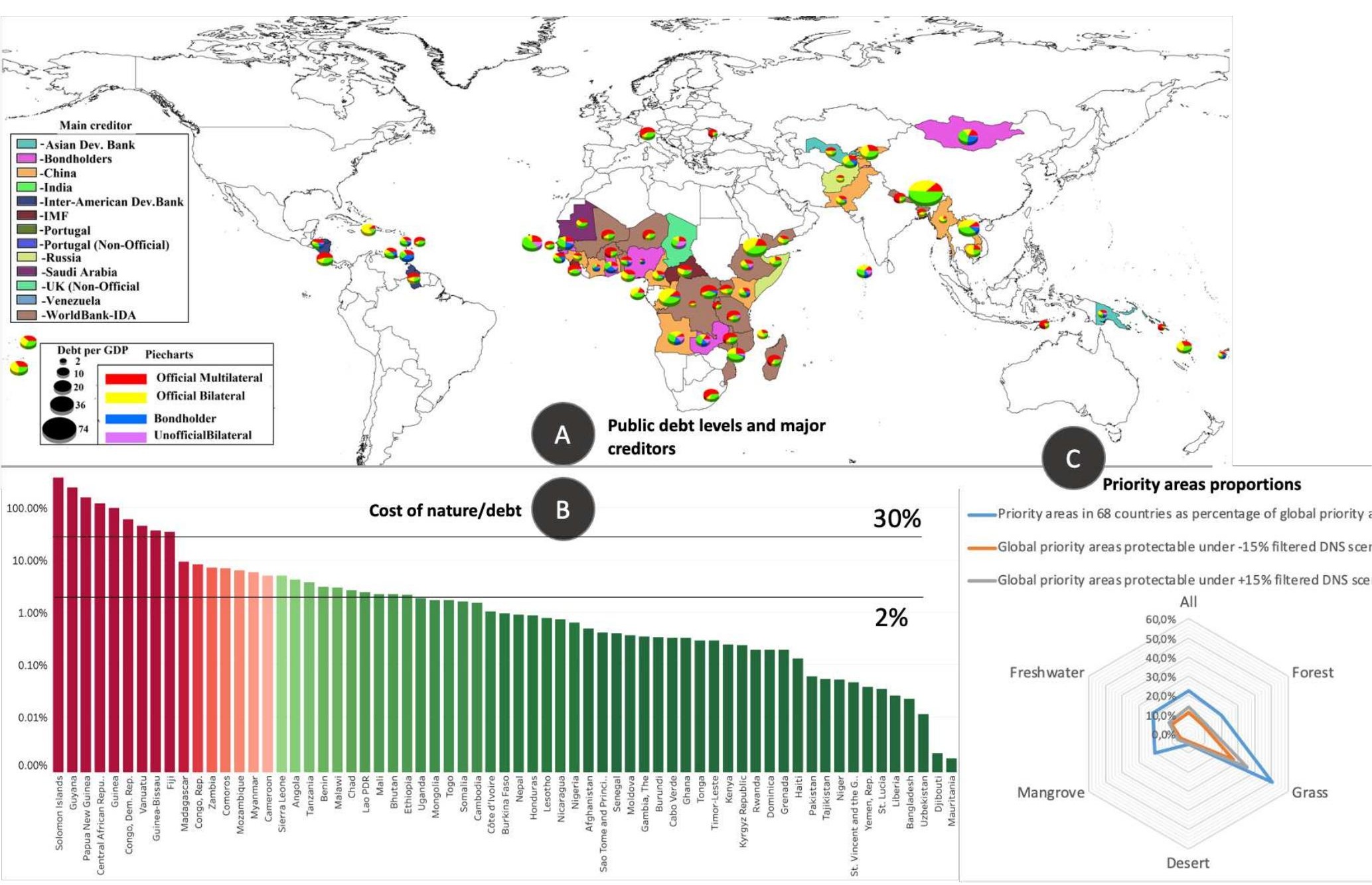

Fig 3 


\section{Baseline cost scenario filtered for 2-30\% DNS application}

...with participation by multilateral creditors

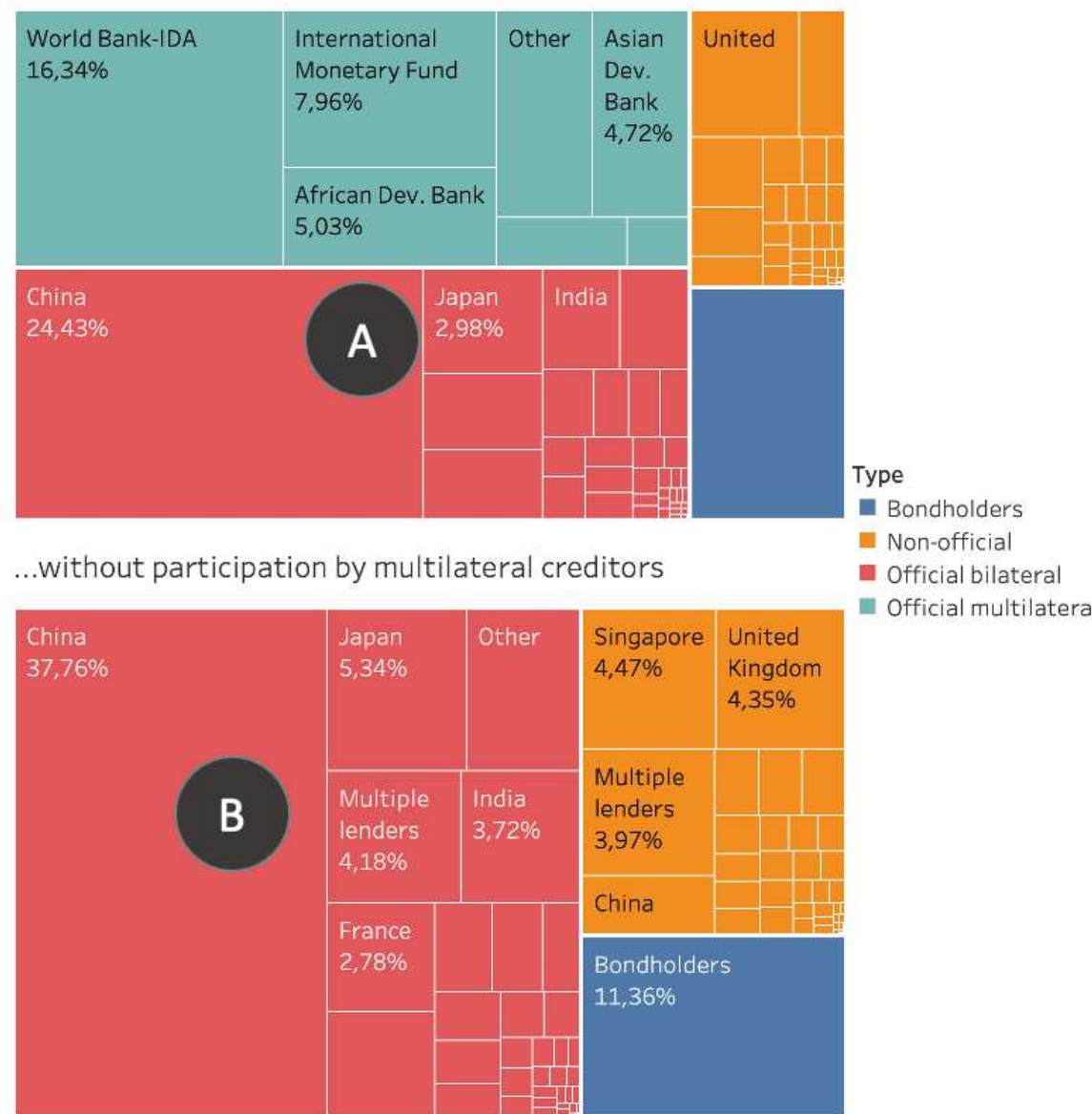

Comparison of baseline scenarios with / without participation multilateral creditors

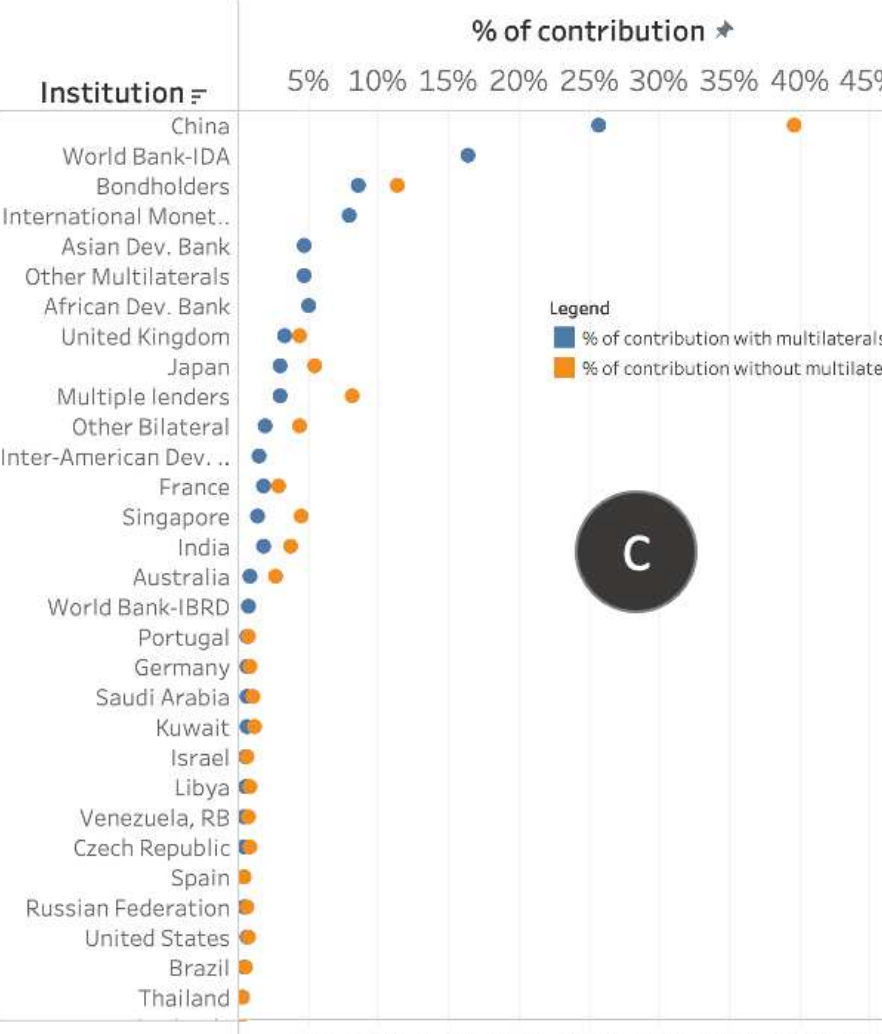

$5 \% \quad 10 \% 15 \% \quad 20 \% 25 \% 30 \% 35 \% \quad 40 \% 45$

Fig 4

\begin{tabular}{|l|l|l|l|l|l|l|}
\hline & $\begin{array}{l}\text { Total share of } \\
\text { global } \\
\text { priority-areas } \\
\text { in selected 67 } \\
\text { countries }\end{array}$ & $\begin{array}{l}\text { Percentage of } \\
\text { priority-areas } \\
\text { protected within } \\
\text { the } 67 \text { countries }\end{array}$ & $\begin{array}{l}\text { Percentage } \\
\text { of priority- } \\
\text { areas } \\
\text { protected } \\
\text { globally }\end{array}$ & $\begin{array}{l}\text { Top five countries with the } \\
\text { highest priority }\end{array}$ & $\begin{array}{l}\text { Highest priority } \\
\text { country's share } \\
\text { of global } \\
\text { priority }\end{array}$ & $\begin{array}{l}\text { Protected } \\
\text { priority-area for } \\
\text { biome } \\
\text { highest } \\
\text { in } \\
\text { priountrity }\end{array}$ \\
\hline Total & $22.32 \%$ & $17.03 \%$ & $15.14 \%$ & $\begin{array}{l}\text { 1. DR Congo } \\
\text { 2. Angola } \\
\text { 3. Mozambique } \\
\text { 4. Central African Republic } \\
\text { 5. Papua New Guinea }\end{array}$ & $5.20 \%$ & $12.70 \%$ \\
\hline Forest & $19.71 \%$ & $16.93 \%$ & $18.66 \%$ & $\begin{array}{l}\text { 1. DR Congo } \\
\text { 2. Angola } \\
\text { 3. Central African Republic } \\
\text { 4. Papua New Guinea } \\
\text { 5. Cameroon }\end{array}$ & $6.47 \%$ & $14.81 \%$ \\
\hline
\end{tabular}




\begin{tabular}{|l|l|l|l|l|l|l|}
\hline Grassland & $50.63 \%$ & $16.61 \%$ & $13.75 \%$ & $\begin{array}{l}\text { 1. Angola } \\
\text { 2. DR Congo } \\
\text { 3. Central African Republic* } \\
\text { 4. Mozambique } \\
\text { 5. Ethiopia }\end{array}$ & $9.51 \%$ & $4.71 \%$ \\
\hline Desert & $5.34 \%$ & $19.63 \%$ & $10.25 \%$ & $\begin{array}{l}\text { 1. Madagascar } \\
\text { 2. Ethiopia } \\
\text { 3. Angola } \\
\text { 4. Mongolia } \\
\text { 5. Pakistan }\end{array}$ & $1.91 \%$ & $21.91 \%$ \\
\hline Mangrove & $20.26 \%$ & $30.15 \%$ & $34.46 \%$ & $\begin{array}{l}\text { 1. Papua New Guinea } \\
\text { 2. Solomon Islands+ } \\
\text { 3. Madagascar } \\
\text { 4. Mozambique } \\
\text { 5. Myanmar }\end{array}$ & $7.41 \%$ & $4.41 \%$ \\
\hline Freshwater & $21.57 \%$ & $28.13 \%$ & $22.92 \%$ & $\begin{array}{l}\text { 1. DR Congo } \\
\text { 2. Papua New Guinea\# } \\
\text { 3. Angola } \\
\text { 4. Zambia } \\
\text { 5. Guyana }\end{array}$ & $7.01 \%$ & $4.08 \%$ \\
\hline
\end{tabular}

Table 1. 


\title{
Supplementary Materials for
}

\section{Debt for nature swaps-which nature, how much and who pays?}

\author{
Christoph Nedopil, Mengdi Yue, Alice C. Hughes*
}

Correspondence to: ach_conservation2@hotmail.com

\section{This PDF file includes:}

Materials and Methods

Supplementary Text

Figs. S1. Total public external debt-to-GDP ratios for 67 DSSI eligible countries by creditor type in 2019

Table S1. Amount of debt needed for DNS by individual creditors

Table S2. Cost of nature

Table S3. Assumed acquisition cost of protected areas in different regions

Captions for Data S1 to S6

Supplementary References

\section{Other Supplementary Materials for this manuscript include the following:}

- Data S1. Priorities and debt on a national basis (Separate table)

- Data S2. Overlaps between species richness hotspots from IUCN/Birdlife and three indices of ecosystem productivity (Separate table)

- Data S3. Overlap between KBAs and priorities, and percentage forest loss since 2000 on a national basis (Separate table)

- Data S4. Debt to GDP of 67 countries eligible for debt for Nature swaps (Separate table)

- Data S5. Links to all data sources used in analysis (Separate table)

- Data S6. Public external debt data in 2019 for 67 DSSI eligible countries (Separate table)

Materials and Methods

Biodiversity prioritization analysis 
Identifying priorities for conservation has been a topic of much discussion for over two decades $(1,2)$. Global2000 and WWF analyses highlighted ecoregions of key importance(3) and since this point many alternate approaches have been used to generate hotspots. Zeroextinction alliance highlighted areas it deemed key to preventing extinction, whereas other prioritization indices highlighted hotspots of threat(4), as well as hotspots of diversity. The advent and growing popularity of species niche models combined with the growing availability of high resolution GIS data, and the growth of platforms such as GBIF for species distribution data provided the opportunity to model species distribution and richness at ever increasing resolutions (5). Yet despite this, and the over 1 billion records in GBIF (6), the vast majority of this data is from birds, and from developed countries. Thus, for larger scale analysis IUCN and birdlife data has become the mainstay of recent analyses, mapping priorities across regions based on species assumed to be present. Yet this data is not only not representative across taxa (7), but includes spatial biases which differ by region and taxa (8). Thus whilst many analyses have used such approaches, their ability to capture key areas for under-represented taxa, unassessed regions, and around political borders is questionable. Given the expediency for the need for conservation in some regions, and possible increases in economically driven landconversion in some developing countries following the pandemic there is an urgent need to protect key areas before they are lost.

In identifying potential hotspots, we aimed to utilize the known relationship between diversity and productivity to identify undisturbed areas with high potential to host diversity. Such an approach overcomes the biases in explicit biodiversity datasets, whilst identifying regions with the potential to maintain diversity, thus providing a more standard metric to develop priorities on global scales and between biomes. Protected areas are known to be able to prevent or reduce deforestation in areas at risk $(9,10)$ and thus given the high rates of deforestation in many of these regions, and small degree of protected area coverage (Data S3) with countries listed showing up to $35 \%$ loss of forest cover since 2000 developing effective protected areas is essential.

Identifying hotspots for prioritization required two main steps (11): firstly, to remove highly disturbed areas, and secondly to identify priority areas within remaining intact habitats. To do this we first created a map of disturbance including population density $(12,13)$, roads and other 
linear infrastructure $(14,15)$, lights at night (16), crops (17), pastureland (18), petrochemical areas $(19,20)$, dams $(21)$, and mines (22). all of which were used at a resolution of $1 \mathrm{~km}^{2}$.

A new updated human footprint was developed at a $1 \mathrm{~km}$ resolution utilizing more recent datasets. Data were treated in a similar way to the original human footprint $(18,23)$, but with some slight changes to better reflect intensity in some layers, and the majority of layers were updated. We did not include waterways in the footprint, as these are natural features and development on them will be signaled by the lights at night layer as well as the impermeable surface (built up) areas layers, removing the need to artificially fragment large forest extents when they lack secondary development. But we retained the pasture map (18) for 2009 and replaced maps for roads (2019), railways (2019), built-up areas (2014), population (2020), cropland (2015) (17), and nights at light (2020) (16). In addition to traditional variables used within the human-footprint, we included petrochemical areas $(19,20)$ dams $(21)$, and mines (22). Original links to data used are available within Data S5.

Similar to former human footprint analyses, each variable was given a value of up to ten based on the level of landscape modification. One layer, pastureland, was maintained from the 2009 analysis as no newer releases of comparable data were available. Each of these layers were scored with values of 0 (no modification) to 10 (intense modification). The values within each layer were based on the original human footprint analysis where possible. In the pasture lands layer (using the same layer as the original human footprint dataset) with values of 2-4 were assigned to different categories of pasture land. For crops, we assigned irrigated crops a value of eight, rainfed a value of seven, and mosaics a value of six based on the scoring scheme from the original HFP. For the population, built-up area, and lights at night layers, each was classified into 10 different zones based on the values, with areas showing almost no modification always giving the value of 10. Equal intervals were used for classification for most factors, but the geometric interval was used for the human population as this was a better match for earlier versions of the human footprint, and better captured the important variations at lower populations (above higher thresholds, additional population will have negligible impact on biodiversity).

For roads and railways, we used the line-density tool in ArcMap 10.3 to explore density at a $1 \mathrm{~km}$ resolution and included a $5 \mathrm{~km}$ buffer-area around each line to calculate density within the 
buffer. This was then reclassified into values between 6-8. Mines (22) and dams were also analysed in terms of density per square kilometer, so more intensely used areas have higher values.

The new human footprint map was then built by aggregating all the data layers together to form a single composite index of modification using the mosaic to new raster function. Areas with a value below 10 in this new composite map were considered as relatively intact and reclassified to zero, whereas all other values were reclassified to "NoData". Thus, this lowdisturbance area provided a mask to assess priorities, as the degree of pressure on these systems were relatively low and likely to represent either no disturbance, or a single form of disturbance which may be possible to restore at a relatively low cost. This approach is also sensible, as it prioritizes areas with the greatest potential for restoration, and the lowest demand for their use (thus not preventing people from accessing resources they need), as well as low or no costs for restoration. This low-disturbance mask was used to extract three indices of productivity; NDVI (a surrogate of Net primary productivity (24)), Leaf area index (LAI) (25), and Enhanced vegetation index (EVI) (26) globally to identify highly productive natural ecosystems. These three indices were chosen because they are known correlates of biodiversity $(25,27)$, but are less likely to be impacted by cloud cover than metrics live Fraction of photosynthetically active radiation (FPAR) $(26,27)$. The 15 global biomes $(28)$ were used to calculate the average productivity for each biome using the zonal statistics function. The 15 biomes were then separated into individual shapefiles, then used to produce a productivity layer for each biome by clipping the productivity for each biome. These productivity layers were then used to identify priority areas for each biome relative to the mean productivity of each biome. These priority areas were ranked into first and second rank priorities based on their productivity and to distinguish between the most productive and less productive areas within each biome.

For forest biomes, many areas had high productivity, so forest biomes were classified to show areas with $50-75 \%$ of maximum richness as the second tier, and $76-100 \%$ as $1^{\text {st }}$ tier. For grassland and desert biomes, the mean NDVI of those biomes was divided in half, and the areas above average richness and top quartile of richness were used. For tundra and rock and ice biomes, the same threshold was used as forest (though very little of this biome fell within the 67 countries). These areas were then re-mosaiced to form a global priority-area layer for all 15 biomes combined. This was repeated for both other productivity layers. The leaf area index for 2020 was downloaded monthly via FTP (M0111222 GLOBE_PROBAV_V1.5.1 from the 
Copernicus site (29)), and average LAI calculated using the mosaic function in ArcMap 10.3. For EVI mean an EVI was reconstructed from the Coefficient of variation and standard deviation files from (StDev/CoV) based on Tuanmu \& Jetz 2015 (30) by first converting to each layer to float then using the divide function to obtain an EVI layer. Thus, all three productivity layers were at $1 \mathrm{~km}$ prior to analysis. Whilst productivity is known to be an effective surrogate of biodiversity $(27,31,32)$, finding the best index for diversity needs some caution. These three indices were then compared to diversity based on birdlife and IUCN data. Whilst these IUCN maps have inherent biases, finding what proportion fall within the priorities from each of the three productivity layers does help guide how well these areas may cover biodiversity hotspots. Biodiversity hotspots were mapped by stacking binary maps for Odonata (2,239 species), Reptilia (10,423 species), Amphibia (6,684 species), Mammalia (2239 species) and Aves (10423 species) using codes and richness layers from Hughes et al., 2021 (8). Richness was then clipped using the modified human footprint layer. The output of this was then treated in two ways for each taxa. Firstly, each was classified into four equal quartiles and the top two retained to form an "overall" hotspot for each group. In addition, each taxa was partitioned into the fourteen biomes, and the top two quartiles for each biome identified and classified to make a binary map for each taxa in each biome, before mosaicking to form biome specific hotspot maps for each taxa and represent the key areas of high diversity for each.

Categories from the three productivity layers were reclassified to values of 1000 and 2000 (for first and second tier priorities), then mosaicked to show when hotspots for each taxa overlapped with each of the productivity derived hotspot maps. The tabulate area tool was then used to calculate the areas of the various combinations of productivity hotspots and biodiversity hotpots in each country. The percentages of biodiversity hotspots falling inside the productivity hotspots for the three different types of productivity analysis for all biodiversity divisions were then calculated. This showed that NDVI covered the highest percentage of biodiversity hotspots, overall (with an average of $88.4 \%$ ), and for both biome specific (92\%) and global hotspots (84.8\%), tables of comparisons are available in Data S2). This shows that whilst NDVI saturates at high levels, these areas are likely to be hyper-diverse, and thus high resolution above a certain thresholds (as provided by EVI) actually limits the amount of diversity captured and makes comparison between biomes more challenging. Whilst NDVI only performed slightly better than EVI, its ability to better enable richness hotspots to be captured across biomes and taxa meant it was the most useful layer for further analysis to identify targets for 
potential DNS. NDVI had the greatest ability to capture diversity layers and is likely the best indicator for this resolution (Data S2).

To subdivide this into important functional classifications, we then masked the global priorities based on five different broad habitat types (forest, freshwater, mangrove, desert and grassland). This was done using high-resolution masks of each habitat, as global biome maps do not differentiate between potential landcover and areas which may have already been converted. To calculate forest and freshwater-riparian priorities, separate layers were used to mask the zones. For mangrove and freshwater-riparian systems, we combined two datasets to provide the most comprehensive coverage of such regions $(33,34)$. The OSM water layer (33) was reclassified to provide only lakes and rivers, then combined with the CIFOR river map to provide a separate classification for freshwater habitats and mangrove habitats and a mask generated for each of these different types of biome. For forests, a forest density layer was used (35) and reclassified to show only forest areas (36) using a threshold density of 30,000 trees per ha. Then, recently deforested areas were removed to show only currently forested areas (37) to provide a high-resolution global forest mask. These three habitat types (forest, freshwater and mangrove) as well as deserts and grasslands (based on Dinerstein 2017 biome maps (28), with the grassland biomes dissolved to form a single mask for grasslands) were used to extract the priority-areas from the global zonal map. Higher-resolution datasets were used for forests and aquatic habitats because these can be challenging to map accurately at broad spatial-scales, and most low-disturbance grassland within the biome is likely to still represent high-value habitats, whereas the global biome map does not provide sufficient data for most aquatic biomes. Furthermore, forest degradation may be detectable from tree density or height, as well as differentiating natural forest from forestry plantations (which tree cover datasets such as global forest watch do not), but detecting over-grazing in grasslands would mainly be identifiable by changes in productivity, and thus already captured. Thus, in all cases we used the highest available resolution as a basis for generating the $1 \mathrm{~km}$ masks to filter priorities for each intact biome.

This provided five habitat-specific layers (forest, desert, grassland, freshwater, and mangrove) as well as the zonal map. To identify priorities within this, we cross-referenced with protected areas by firstly dissolving all GIS protected areas listed within WDPA (39) then converting them to rasters and reclassifying all to a value of 100 . This was then combined with the zonal 
priority map in addition to the five biome-specific maps using the sum function in mosaic to new raster so that protected priorities of each potential richness level and its protection status could be assayed.

The calculate area tool was then used to calculate the area of each zone of each priority within each country by overlaying each of the five "biome" priority maps, and the overall priority map with an administrative map of the world. This means that total priorities include biomes (such as tundra and rock and ice) which have priorities but were not analysed separately as they include little or no area in DSSI countries, and are also less diverse than other biomes. Furthermore, some biomes examined necessarily overlap: tall mangroves can be considered forests and host both aquatic and terrestrial species, and riparian areas include swamps, forests, and various other ecosystems which may therefore be listed as a priority under more than one dimension, and is likely to span greater diversity and heterogeneity.

To assess how well our priorities match previously identified key areas for biodiversity we assayed the overlap between our priorities and the Key Biodiversity Areas mapped through Birdlife International. KBAs were not used as a target as different countries have different approaches to KBA listing, and many KBAs evolved from important bird areas (IBAs), thus whilst the dataset is a useful comparator it is not representative at a taxonomic level (and many miss any assessments for many taxa), or at a national level when compared between countries. Relative to Key Biodiversity Areas (KBAs: http://www.keybiodiversityareas.org/), our priorities performed well in most countries, with a high degree of coverage in the most diverse biomes (Data S3). However, the overlap was notably lower in countries with dryer biomes. This is likely due to very small KBAs and ecosystems in some of these cases (i.e., single sections of a river), and a lower diversity than similar systems in other countries. Such systems are likely to rely on the identification of species based on intense surveys, and thus are not necessarily standardized between countries and regions. Furthermore, in these cases, such KBAs are often either already protected, or are at low risk due to inaccessibility, etc. Thus, in the regions with the highest levels of diversity and rates of habitat loss (i.e., deforestation for percentage forest loss since 2000, based on a data request from global forest watch (https://www.globalforestwatch.org/); see Data S3), our priorities perform well, and often include over $90 \%$ of existing KBAs, thus providing a complementary tool for the identification of priorities for protection, even without comprehensive and comparable data on species 
occurrence in many areas. This analysis shows that the priority-areas highlighted here perform well, and provide an effective way to map priorities at a large scale, without the need for direct biodiversity data. Furthermore, such an approach can be applied in concert with other remote sensing approaches to enable coherent and standard metrics for the monitoring as well as prioritization of key areas for biodiversity at any scale.

Debt analysis

To understand "whose debt" is applicable for debt-for-nature swaps post COVID-19, we first identified "public external debt stock" as the type of debt relevant for analysis. In this term, "public" refers to debt owed by a public agency or a private agency with a public guarantee in the debtor country, and "external" refers to debt owed to nonresidents (39). By this, we make sure that our analysis aligns with the cases of past debt-for-nature swaps, which were generally implemented between the debtor government and one or more foreign lenders (usually the creditor governments).

We then narrowed down the group of debtor countries under analysis to the 73 countries eligible for Debt Service Suspension Initiative (DSSI) as they are more vulnerable to debt distress and have a higher priority for debt restructuring, including debt swaps. In response to the COVID-19, G20 established DSSI in May 2020 to provide temporary suspension of debtservice payments owed to official bilateral creditors until December 2021 (40). In November 2020, the "Common Framework for Debt Treatments beyond the DSSI" was launched by G20 that also requires comparable debt relief from private creditors in addition to that from public creditors $(41)$.

Debt data for 67 out of the 73 DSSI eligible countries (detailed data for South Sudan, Micronesia, Tuvalu, Kiribati, and the Marshall Islands are not available and Kosovo is not universally recognized as a country) were obtained from the World Bank International Debt Statistics (IDS). IDS contains country-level data of public external debt stocks owed to four types of non-resident lenders: 1) official multilateral creditors, i.e., international organizations whose membership and decision-making process includes the government of two or more countries, such as the IMF, the World Bank, Asian Development Bank; 2) official bilateral creditors, i.e., lending by sovereign governments and all public institutions in which the government share is 50 percent or above and encompassed of the general government, central government; state and local government; central bank; and public enterprise; 3) bondholders, 
i.e., holdings of securities by investors for which the issuer has promised to pay a specified amount of money at a fixed date and income at periodic dates until maturity, including publicly placed bonds and privately placed bonds; and 4) non-official creditors include all other private creditors, including those that are officially supported by an export credit guarantee, or other forms of risk-mitigating guarantee, from an official bilateral entity or multilateral institution (39).

The sizes of total and disaggregated public external debts are measured as percentages of the debtor country's GDP (debt-to-GDP ratios), in line with the IMF Debt Sustainability Analysis (42). GDP data for individual debtor countries were obtained from the World Bank, except Somalia's from IMF. We used data in 2019 as they are the most current and complete data available while assuming that the overall debt levels and debt ratios in the 67 countries would be higher in 2020 due to economic recession and increased public spending.

The distribution of debt owed to different types of creditors in comparison to debtor country GDP is as follows (see Supplementary Figure 1).

\section{Official multilateral creditors}

Official multilateral creditors are multilateral bodies or banks, such as the World Bank or IMF, and account for $46 \%$ of total public external debt in the 67 DSSI countries. They are the largest creditors in 32 of the 67 countries.

Particularly:

World Bank-IDA is the most important creditor in 21 countries, including Mozambique, Rwanda, Lesotho, Liberia and Malawi (top 5 with the highest level of IDA debt to GDP ratios). Inter-American Development Bank is the largest lender in Nicaragua, Guyana and Honduras; IMF is the largest creditor in Sierra Leone, Burundi, Kosovo and Central Africa Republic; Asian Development Bank is particularly prominent in Uzbekistan, Timor-Leste, Papua New Guinea and Solomon Islands.

\section{Official bilateral creditors}

Official bilateral creditors are state-level lenders and account for $34 \%$ of total public external debt in the 67 DSSI countries. Many emerging economies are borrowing money predominantly from other emerging markets. China, for example, is the major bilateral official lender in 20 countries including Djibouti, Republic of Congo, Lao PDR, Kyrgyz Republic and Tonga (top 
5 with highest levels of Chinese debt-to-GDP ratios). India is the single largest creditor in Bhutan whose debt accounts for 74\% of Bhutan's GDP in 2019. Russia is the largest creditor in Somalia and Afghanistan; Saudi Arabia is the largest creditor of Mauritania, while Haiti's debt is predominantly from Venezuela.

\section{Bondholders}

Private bondholders are individuals or companies based within a country and account for $13 \%$ of total public external debt in the 67 DSSI countries. They are the largest creditors in eight countries: Mongolia, Senegal, Zambia, St. Lucia, Ghana, Guinea-Bissau, Dominica, and Nigeria.

\section{Non-official creditors}

Non-official creditors account for only $7 \%$ of total public external debt in the 67 DSSI countries. They are the largest creditors in 2 countries: over a quarter of Cabo Verde's public external debt is owed to non-official lenders from Portugal; while the largest creditor in Chad is commercial banks in the UK.

To calculate how much debt each creditor would have to swap for nature, we assumed fair distribution of the swap across all creditors for every single country. Accordingly, we calculated the cost for each creditor in each debtor country and could sum up the total debt to be swapped under the different scenarios.

\section{$\underline{\text { Acquisition and management cost of protected areas }}$}

To calculate the cost of nature conservation, we distinguished between the acquisition cost and management cost of protected areas, but we did not consider opportunity cost (43-45).

To estimate these costs, we analyzed data from previous debt-for-nature swaps and nature conversion projects (Data S5). We further analyzed data for protected areas cost from numerous secondary sources, such as McCarthy et al.(46), Gantioler et al. (47), Frazee et al. (48), and Waldron et al. (44). In all cases, cost estimates varied widely, with a clear finding that data are incomplete and highly context-specific. For example, Waldron et al. find that to acquire $30 \%$ of nature (both water and land) by 2030 in over 100 emerging economies (including large countries, such as Brazil, Argentina and Chile, which are not part of our study), 
prices range from USD300 to USD700 billion, acknowledging big differences between biomes and high costs particularly for marine ecosystem protection.

We further engaged in interviews with researchers and experts from nature conservation groups experienced in pricing nature conservation and previous application of DNS, such as WWF, Friends of Earth, The Nature Conservancy. We found that while prices are sometimes economically determined (e.g., based on alternate land use to conservation), the prices for DNS - and in particular for acquisition costs are often more politically determined for land that is not privately owned (the majority of our focus).

Accordingly, we expect prices to vary across countries and biomes. For desert protection, prices are likely lower given the land is less productive and under less pressure, while for more arable areas with high population growth prices might be slightly higher. Many of these pressures will be highest in the African continent, where a minority of potential agricultural land is currently used in some countries (i.e., D.R. Congo) and where demographically population is still increasing. However, the need to develop sustainably, especially to maintain key resources such as water, is an additional reason to use approaches such as debt-for-nature swaps to safeguard key ecosystem services and functions. Mineral resources etc. are not considered here, as it would be too speculative.

To further understand management costs, we directly reached out to operators of protected areas. We confirmed previous literature that operating costs depend on local personnel costs, vehicles (including boats for mangrove areas), and infrastructure costs to prevent unsustainable use through hunting or deforestation. Accordingly, operating costs will vary based on the frequency of patrols needed, the circumference of the area and the local salary expectations.

Accordingly, based on (a) interviews and desk research, (b) assumption of political willingness in debtor countries to engage in DNS, (c) the fact that the focus of our DNS is on conservation, not restoration (which should make it cheaper), and (d) that regional price differences would exist, we concluded that prices are, if anything, impossible to predict and that prices would be negotiable. To nevertheless provide relevant estimates for costs, we applied prices that allowed us to differentiate at least between regions as surveyed by James et al (49) and Waldron et al.(44). Accordingly, we adjusted their values to 2019 USD. To allow for a broader flexibility, we further calculated scenarios with prices $15 \%$ higher and $15 \%$ lower than those suggested by James et al. 2021 
To estimate management cost, we followed the approach in Bohorquez et al. (45) on ratios between acquisition and management cost of terrestrial protected areas. The authors found that depending on the survey, the ratio range from 0.49 to 25.5 , with an average of 8.64 . Conservatively, we estimate the average annual management cost for protected areas to be $31 \%$ of the acquisition cost.

To calculate regular service payments from the swapped debt (service payments are swapped from interest payments), we find in the World Bank data current interest rates in DSSI countries vary between 0 to $6 \% 1$. We take an average interest rate of $3 \%$. We further assume a $30 \%$ discount on the debt-related payments, which is considerably more than on previous debt swaps: e.g., in the 2018 Seychelles DNS, the discount rate was 5.4\%. This discount rate means that if USD1 million of debt would be swapped, the debtor country would have to pay $2.5 \%$ on USD0.7 million (USD17,500) per year to the environmental trust fund.

Once all costs are established, the acquisition and management costs for protecting priority areas for each country could be calculated, as well as the financing gap, particularly for the management costs.

1 For example, Angola pays USD1.372 million in 2020 for interest on a total public debt of USD36.4 million, equaling 4\% interest payment: https://datatopics.worldbank.org/dssitables/annual/AGO, accessed May 18, 2021 
Fig. $\underline{\text { S1. }}$.

Total public external debt-to-GDP ratios for 67 DSSI eligible countries by creditor type in 2019 (data source: World Bank and IMF).

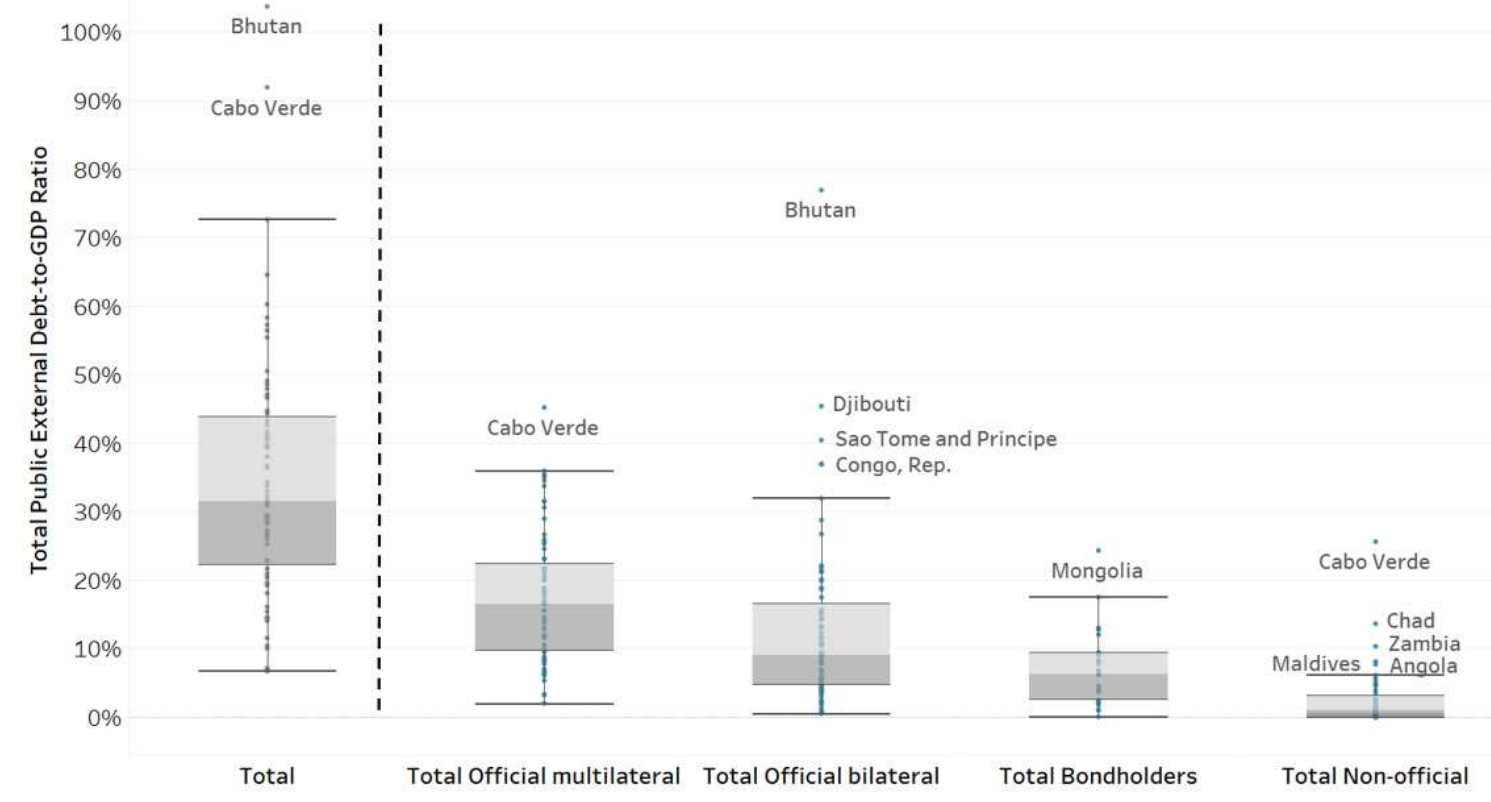




\section{Amount of debt needed for DNS by individual creditors.}

To calculate how much debt each creditor would have to swap for nature, we assumed fair distribution of the swap across all creditors for every single country. Accordingly, after filtering for a minimum of $2 \%$ applicable debt and maximize at $30 \%$ debt swap, we calculated the cost for each creditor in each debtor country and could sum up the total debt to be swapped under the different scenarios cost scenarios. We calculated both the debt needed for swapping under the assumption of no participation/participation of multilateral lenders.

\begin{tabular}{|c|c|c|c|c|c|c|c|}
\hline \multirow[b]{2}{*}{ Type } & \multirow[b]{2}{*}{ Institution } & \multicolumn{3}{|c|}{ With participations of multilateral lenders } & \multicolumn{3}{|c|}{$\begin{array}{l}\text { Without participation by multilateral } \\
\text { lenders }\end{array}$} \\
\hline & & $\begin{array}{l}\text { baseline } \\
\text { scenario }\end{array}$ & $\begin{array}{l}\text { plus } 15 \% \\
\text { scenario }\end{array}$ & $\begin{array}{l}\text { minus } 15 \\
\text { scenario }\end{array}$ & $\begin{array}{l}\text { baseline } \\
\text { scenario }\end{array}$ & $\begin{array}{l}\text { plus } 15 \% \\
\text { scenario }\end{array}$ & $\begin{array}{l}\text { minus } 15 \\
\text { scenario }\end{array}$ \\
\hline $\begin{array}{l}\text { Bondhol } \\
\text { ders }\end{array}$ & Bondholders & $\begin{array}{r}926,344,00 \\
7\end{array}$ & $\begin{array}{r}1,042,794,3 \\
48\end{array}$ & $\begin{array}{r}832,182,55 \\
9\end{array}$ & $\begin{array}{r}1,573,570,0 \\
92 \\
\end{array}$ & $\begin{array}{r}1,768,531,1 \\
19 \\
\end{array}$ & $\begin{array}{r}1,418,926,1 \\
97\end{array}$ \\
\hline \multirow[t]{19}{*}{$\begin{array}{l}\text { Non- } \\
\text { official }\end{array}$} & Angola & $6,000,000$ & $6,000,000$ & $6,000,000$ & $14,842,719$ & $14,842,719$ & $14,842,719$ \\
\hline & Austria & $5,647,626$ & $6,494,770$ & $4,347,723$ & $9,119,827$ & $10,487,802$ & $7,148,678$ \\
\hline & Bahamas & 69,444 & 79,861 & 59,027 & 404,807 & 465,528 & 344,086 \\
\hline & Bahrain & - & - & - & - & - & - \\
\hline & Barbados & - & - & - & - & - & - \\
\hline & Belgium & $14,477,134$ & $16,699,637$ & $12,305,564$ & $33,190,027$ & $38,471,548$ & $28,211,523$ \\
\hline & Brazil & 233,240 & 268,226 & 198,254 & 420,004 & 483,005 & 357,004 \\
\hline & Canada & $5,223,165$ & $6,006,639$ & $4,439,690$ & $5,998,474$ & $6,898,245$ & $5,098,703$ \\
\hline & China & $\begin{array}{r}132,297,66 \\
6 \\
\end{array}$ & $\begin{array}{r}150,306,87 \\
9 \\
\end{array}$ & $79,336,066$ & $\begin{array}{r}251,217,01 \\
1 \\
\end{array}$ & $\begin{array}{r}284,918,03 \\
5 \\
\end{array}$ & $\begin{array}{r}153,380,41 \\
4 \\
\end{array}$ \\
\hline & $\begin{array}{l}\text { Cote D’Ivoire, } \\
\text { Republic Of }\end{array}$ & $4,056,206$ & $4,664,637$ & $3,447,775$ & $10,728,432$ & $12,337,697$ & $9,119,167$ \\
\hline & $\begin{array}{l}\text { Czech } \\
\text { Republic }\end{array}$ & $23,741,100$ & $23,741,100$ & $23,741,100$ & $97,751,411$ & $97,751,411$ & $97,751,411$ \\
\hline & Denmark & $8,888,032$ & $10,221,237$ & $7,554,827$ & $29,288,751$ & $33,682,063$ & $24,895,438$ \\
\hline & Egypt & 1,759 & 2,022 & - & 3,194 & 3,673 & - \\
\hline & France & $13,871,741$ & $15,935,672$ & $5,864,166$ & $21,699,408$ & $24,912,685$ & $7,690,022$ \\
\hline & Germany & $16,293,560$ & $18,938,447$ & $13,849,526$ & $59,546,306$ & $69,673,183$ & $50,614,360$ \\
\hline & Greece & 686,488 & 789,461 & 583,515 & $1,815,721$ & $2,088,079$ & $1,543,362$ \\
\hline & Grenada & - & - & - & - & - & - \\
\hline & Hong Kong & $3,986,235$ & $4,584,170$ & $3,388,300$ & $14,010,782$ & $16,112,399$ & $11,909,165$ \\
\hline & Hungary & 216,785 & 249,302 & 184,267 & $1,568,787$ & $1,804,105$ & $1,333,469$ \\
\hline
\end{tabular}




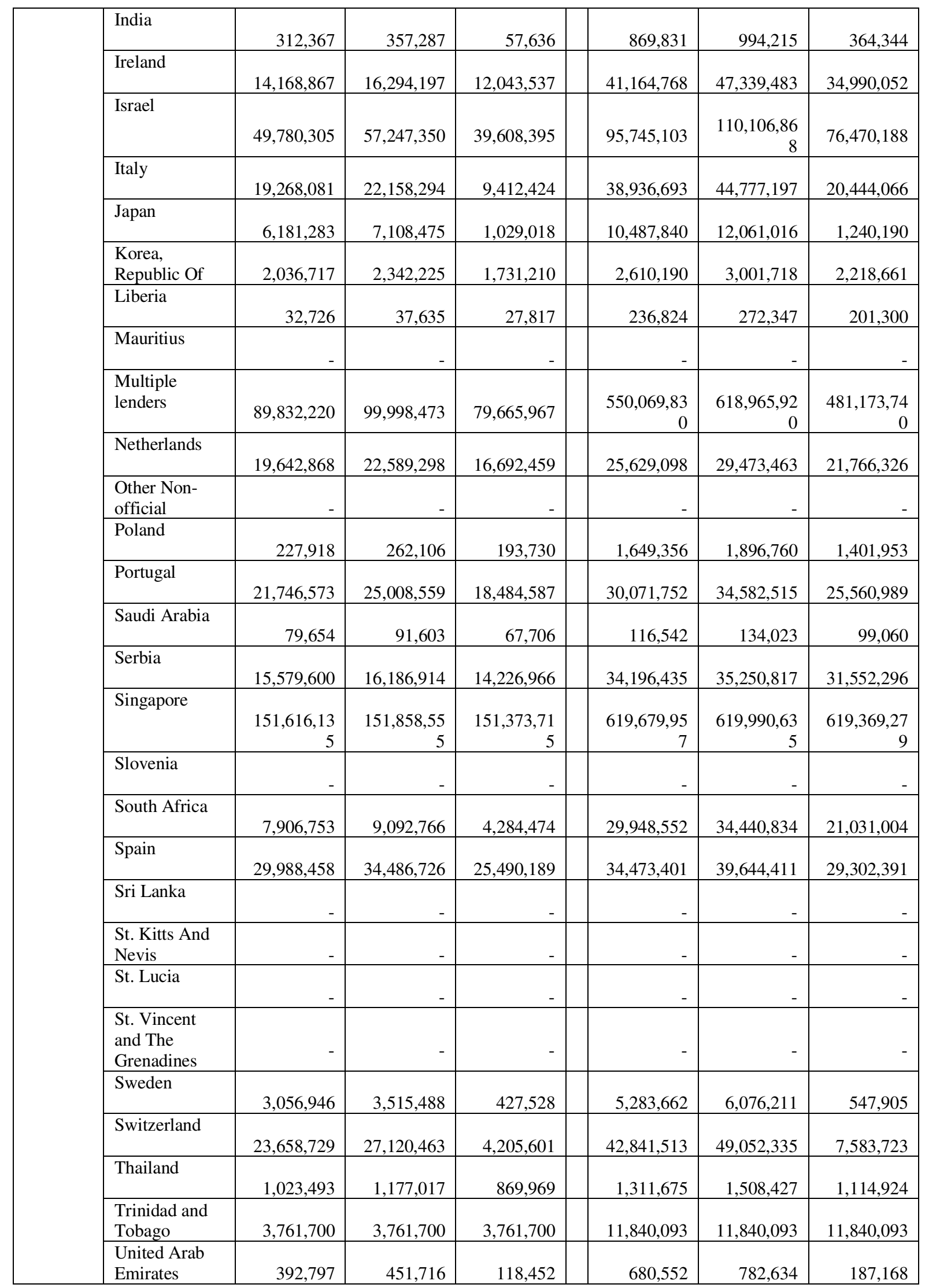




\begin{tabular}{|c|c|c|c|c|c|c|c|}
\hline & $\begin{array}{l}\text { United } \\
\text { Kingdom }\end{array}$ & $\begin{array}{r}353,233,86 \\
0 \\
\end{array}$ & $\begin{array}{r}406,917,64 \\
7 \\
\end{array}$ & $\begin{array}{r}294,251,65 \\
9 \\
\end{array}$ & $\begin{array}{r}602,704,01 \\
6 \\
\end{array}$ & $\begin{array}{r}699,699,76 \\
8 \\
\end{array}$ & $\begin{array}{r}502,352,55 \\
4\end{array}$ \\
\hline & United States & $55,687,337$ & $63,885,188$ & $22,140,403$ & $94,069,653$ & $\begin{array}{r}107,691,44 \\
6\end{array}$ & $34,403,467$ \\
\hline \multirow[t]{24}{*}{$\begin{array}{l}\text { Official } \\
\text { bilateral }\end{array}$} & Argentina & $1,354,500$ & $1,354,500$ & $1,354,500$ & $4,263,340$ & $4,263,340$ & $4,263,340$ \\
\hline & Australia & $90,000,000$ & $90,000,000$ & $90,000,000$ & $\begin{array}{r}370,565,26 \\
3\end{array}$ & $\begin{array}{r}370,565,26 \\
3\end{array}$ & $\begin{array}{r}370,565,26 \\
3\end{array}$ \\
\hline & Austria & $8,309,612$ & $9,632,165$ & $6,561,964$ & $11,249,908$ & $13,390,205$ & $8,542,421$ \\
\hline & Belarus & - & - & - & - & - & - \\
\hline & Belgium & $2,141,955$ & $2,463,248$ & $1,742,148$ & $10,826,924$ & $12,450,963$ & $8,839,579$ \\
\hline & Brazil & $32,091,445$ & $36,905,161$ & $27,277,728$ & $54,218,434$ & $62,351,199$ & $46,085,669$ \\
\hline & Canada & $16,371,396$ & $18,827,105$ & $12,599,146$ & $19,836,119$ & $22,811,537$ & $14,469,322$ \\
\hline & China & $\begin{array}{r}2,644,796,2 \\
83 \\
\end{array}$ & $\begin{array}{r}3,009,835,8 \\
30 \\
\end{array}$ & $\begin{array}{r}2,209,482,0 \\
03 \\
\end{array}$ & $\begin{array}{r}5,228,580,4 \\
26 \\
\end{array}$ & $\begin{array}{r}6,033,107,9 \\
95 \\
\end{array}$ & $\begin{array}{r}4,446,624,5 \\
78 \\
\end{array}$ \\
\hline & $\begin{array}{l}\text { Czech } \\
\text { Republic }\end{array}$ & $8,023,142$ & $8,718,951$ & $6,818,559$ & $13,516,588$ & $14,442,828$ & $11,487,080$ \\
\hline & Denmark & - & - & ( & 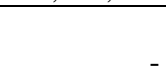 & 2. & 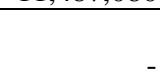 \\
\hline & Egypt & $1,414,745$ & $1,429,799$ & $1,202,534$ & $3,068,941$ & $3,101,597$ & $2,608,600$ \\
\hline & Finland & 164,489 & 189,162 & 139,816 & 210,804 & 242,424 & 179,183 \\
\hline & France & $\begin{array}{r}180,717,40 \\
2 \\
\end{array}$ & $\begin{array}{r}207,188,72 \\
9 \\
\end{array}$ & $\begin{array}{r}146,609,20 \\
1 \\
\end{array}$ & $\begin{array}{r}385,028,94 \\
4 \\
\end{array}$ & $\begin{array}{r}453,051,26 \\
6 \\
\end{array}$ & $\begin{array}{r}306,241,75 \\
3 \\
\end{array}$ \\
\hline & Germany & $45,439,833$ & $51,979,733$ & $38,397,390$ & $64,360,178$ & $72,877,496$ & $54,930,034$ \\
\hline & $\begin{array}{l}\text { Germany, } \\
\text { Fed.Rep. Of }\end{array}$ & - & - & 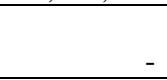 & 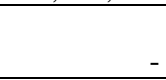 & s & (2) \\
\hline & Hungary & $1,838,346$ & $2,114,098$ & $1,562,594$ & $2,215,606$ & $2,547,947$ & $1,883,265$ \\
\hline & India & $\begin{array}{r}201,162,93 \\
9 \\
\end{array}$ & $\begin{array}{r}226,963,12 \\
3 \\
\end{array}$ & $\begin{array}{r}137,592,40 \\
3 \\
\end{array}$ & $\begin{array}{r}515,249,20 \\
3 \\
\end{array}$ & $\begin{array}{r}581,281,93 \\
2 \\
\end{array}$ & $\begin{array}{r}391,182,39 \\
2 \\
\end{array}$ \\
\hline & $\begin{array}{l}\text { Iran, Islamic } \\
\text { Republic Of }\end{array}$ & $2,913,791$ & $3,350,860$ & $2,476,722$ & $21,085,989$ & $24,248,887$ & $17,923,090$ \\
\hline & Italy & $4,948,024$ & $5,575,433$ & $1,821,661$ & $9,234,140$ & $10,257,939$ & $3,671,208$ \\
\hline & Japan & $\begin{array}{r}322,614,94 \\
1 \\
\end{array}$ & $\begin{array}{r}370,464,46 \\
4 \\
\end{array}$ & $\begin{array}{r}280,412,62 \\
6 \\
\end{array}$ & $\begin{array}{r}739,323,65 \\
7 \\
\end{array}$ & $\begin{array}{r}859,998,70 \\
9 \\
\end{array}$ & $\begin{array}{r}656,378,10 \\
9 \\
\end{array}$ \\
\hline & Kuwait & $53,874,462$ & $59,128,573$ & $45,014,576$ & $\begin{array}{r}166,734,73 \\
9\end{array}$ & $\begin{array}{r}187,217,96 \\
2\end{array}$ & $\begin{array}{r}138,059,13 \\
2\end{array}$ \\
\hline & Libya & $49,576,419$ & $54,970,170$ & $38,387,223$ & $\begin{array}{r}112,268,73 \\
4 \\
\end{array}$ & $\begin{array}{r}123,852,98 \\
6 \\
\end{array}$ & $88,059,115$ \\
\hline & Malaysia & $1,061,190$ & $1,220,368$ & 902,011 & $1,278,963$ & $1,470,808$ & $1,087,119$ \\
\hline & $\begin{array}{l}\text { Multiple } \\
\text { lenders }\end{array}$ & $\begin{array}{r}231,305,69 \\
8 \\
\end{array}$ & $\begin{array}{r}264,317,47 \\
9 \\
\end{array}$ & $\begin{array}{r}196,609,84 \\
3 \\
\end{array}$ & $\begin{array}{r}579,250,49 \\
2 \\
\end{array}$ & $\begin{array}{r}662,484,88 \\
5\end{array}$ & $\begin{array}{r}492,362,91 \\
9\end{array}$ \\
\hline
\end{tabular}




\begin{tabular}{|c|c|c|c|c|c|c|c|}
\hline & Netherlands & 636,888 & 732,421 & 541,355 & 799,215 & 919.097 & 679,332 \\
\hline & Nigeria & & & & & & \\
\hline & & - & 192,040 & - & - & $1,142,502$ & - \\
\hline & Norway & $2,853,048$ & $3,281,005$ & $2,425,091$ & $4,838,390$ & $5,564,148$ & $4,112,631$ \\
\hline & Other Bilateral & $\begin{array}{r}212,013,20 \\
3\end{array}$ & $\begin{array}{r}233,847,81 \\
4\end{array}$ & $\begin{array}{r}176,982,64 \\
5\end{array}$ & $\begin{array}{r}606,833,67 \\
5\end{array}$ & $\begin{array}{r}670,787,97 \\
5\end{array}$ & $\begin{array}{r}519,601,51 \\
6\end{array}$ \\
\hline & Portugal & $45,343,336$ & $52,144,836$ & $38,541,835$ & $69,684,481$ & $80,137,153$ & $59,231,808$ \\
\hline & $\begin{array}{l}\text { Russian } \\
\text { Federation }\end{array}$ & $37,118,123$ & $42,685,841$ & $28,605,069$ & $94,964,325$ & $\begin{array}{r}109,208,97 \\
4\end{array}$ & $75,369,732$ \\
\hline & Saudi Arabia & $59,772,465$ & $64,239,126$ & $49,914,619$ & $\begin{array}{r}148,486,53 \\
2\end{array}$ & $\begin{array}{r}163,380,14 \\
4\end{array}$ & $\begin{array}{r}120,869,67 \\
5\end{array}$ \\
\hline & Spain & $3,812,141$ & $4,383,962$ & $3,240,320$ & $7,306,300$ & $8,402,245$ & $6,210,355$ \\
\hline & Sweden & $1,099,417$ & $1,264,330$ & 934,505 & $7,054,995$ & $8,113,244$ & $5,996,745$ \\
\hline & Switzerland & $2,053,548$ & $2,075,399$ & $1,745,516$ & $4,454,665$ & $4,502,066$ & $3,786,465$ \\
\hline & Thailand & $25,366,113$ & $29,117,666$ & $21,561,196$ & $31,562,744$ & $36,181,395$ & $26,828,333$ \\
\hline & Turkey & $20,598,841$ & $23,688,668$ & $13,134,159$ & $32,546,762$ & $37,428,776$ & $19,718,204$ \\
\hline & $\begin{array}{l}\text { United Arab } \\
\text { Emirates }\end{array}$ & $2,984,910$ & $3,368,910$ & $2,147,930$ & $9,278,645$ & $10,699,872$ & $5,873,835$ \\
\hline & $\begin{array}{l}\text { United } \\
\text { Kingdom }\end{array}$ & $2,156,577$ & $5,727,665$ & $1,837,230$ & $3,030,273$ & $22,817,394$ & $2,588,763$ \\
\hline & United States & $6,841,432$ & $7,846,002$ & $5,836,862$ & $11,503,844$ & $13,161,292$ & $9,846,396$ \\
\hline & Venezuela, RB & $32,923,200$ & $32,923,200$ & $32,923,200$ & $\begin{array}{r}103,627,01 \\
5\end{array}$ & $\begin{array}{r}103,627,01 \\
5\end{array}$ & $\begin{array}{r}103,627,01 \\
5\end{array}$ \\
\hline $\begin{array}{l}\text { Official } \\
\text { multilate } \\
\text { ral }\end{array}$ & $\begin{array}{l}\text { African Dev, } \\
\text { Bank }\end{array}$ & $\begin{array}{r}544,405,72 \\
1 \\
\end{array}$ & $\begin{array}{r}650,672,58 \\
8 \\
\end{array}$ & $\begin{array}{r}410,242,44 \\
9 \\
\end{array}$ & & & \\
\hline & $\begin{array}{l}\text { Asian Dev, } \\
\text { Bank }\end{array}$ & $\begin{array}{r}510,551,82 \\
0 \\
\end{array}$ & $\begin{array}{r}523,843,17 \\
3 \\
\end{array}$ & $\begin{array}{r}528,769,37 \\
6 \\
\end{array}$ & & & \\
\hline & $\begin{array}{l}\text { International } \\
\text { Monetary } \\
\text { Fund } \\
\end{array}$ & $\begin{array}{r}861,340,99 \\
7 \\
\end{array}$ & $\begin{array}{r}948,504,67 \\
8 \\
\end{array}$ & $\begin{array}{r}763,719,92 \\
7 \\
\end{array}$ & & & \\
\hline & $\begin{array}{l}\text { Other } \\
\text { Multilaterals }\end{array}$ & $\begin{array}{r}514,486,73 \\
6 \\
\end{array}$ & $\begin{array}{r}581,610,20 \\
0\end{array}$ & $\begin{array}{r}420,520,01 \\
5\end{array}$ & & & \\
\hline & $\begin{array}{l}\text { World Bank- } \\
\text { IBRD }\end{array}$ & $77,206,515$ & $87,976,682$ & $81,874,513$ & & & \\
\hline & $\begin{array}{l}\text { World Bank- } \\
\text { IDA }\end{array}$ & $\begin{array}{r}1,768,854,8 \\
88 \\
\end{array}$ & $\begin{array}{r}2,058,626,7 \\
45 \\
\end{array}$ & $\begin{array}{r}1,319,986,3 \\
87 \\
\end{array}$ & & & \\
\hline & $\begin{array}{l}\text { Inter- } \\
\text { American } \\
\text { Dev. Bank }\end{array}$ & $\begin{array}{r}163,854,00 \\
0 \\
\end{array}$ & $\begin{array}{r}163,854,00 \\
0\end{array}$ & $\begin{array}{r}163,854,00 \\
0\end{array}$ & & & \\
\hline
\end{tabular}


Table $\underline{\text { S2. }}$

Cost of nature

\begin{tabular}{|c|c|c|c|c|c|c|c|}
\hline Region & Country & Type & Time & Land Type & Land Use & $\begin{array}{l}\text { Price in } \\
2020(\mathrm{USD} \\
\text { per } \mathrm{km}^{2} \text { ) }\end{array}$ & Includes \\
\hline America & Bolivia (50) & DNS & 1987 & $\begin{array}{l}\text { Tropical } \\
\text { forest }\end{array}$ & $\begin{array}{l}\text { Conservation } \\
\text { areas for Buffer } \\
\text { zones }\end{array}$ & 130 & Acquisition \\
\hline Africa & $\begin{array}{l}\text { Tanzania } \\
\text { Rondo } \\
\text { Plateau (51) }\end{array}$ & $\begin{array}{l}\text { Private } \\
\text { Conservation } \\
\text { group }\end{array}$ & $\begin{array}{l}2021 \\
\text { Fully } \\
\text { funded }\end{array}$ & $\begin{array}{l}\text { Coastal } \\
\text { Forests }\end{array}$ & $\begin{array}{l}10 \text { Reserves for } \\
\text { lions, leopards, } \\
\text { chameleons, } \\
\text { birds and } \\
\text { primate } \\
\text { communities }\end{array}$ & 2,220 & Acquisition \\
\hline $\begin{array}{l}\text { South } \\
\text { America }\end{array}$ & Bolivia (52) & $\begin{array}{l}\text { Private } \\
\text { conservation } \\
\text { group (ICFC) }\end{array}$ & $\begin{array}{l}\text { 2010-now } \\
\text { Ongoing }\end{array}$ & $\begin{array}{l}\text { Beni } \\
\text { Savanna }\end{array}$ & $\begin{array}{l}\text { Conservation } \\
\text { of the blue- } \\
\text { throated macaw }\end{array}$ & 2,645 & $\begin{array}{l}\text { Acquisition and } \\
\text { management }\end{array}$ \\
\hline $\begin{array}{l}\text { North } \\
\text { America }\end{array}$ & Mexico (53) & $\begin{array}{l}\text { Commercial } \\
(\mathrm{NCI})\end{array}$ & $\begin{array}{l}\text { NA } \\
\text { (ongoing) }\end{array}$ & $\begin{array}{l}\text { Tropical dry } \\
\text { forests land }\end{array}$ & $\begin{array}{l}\text { Habitat for } \\
\text { tropical } \\
\text { rainforest }\end{array}$ & 9,880 & $\begin{array}{l}\text { Acquisition and } \\
\text { management }\end{array}$ \\
\hline Asia & China (54) & government & 1999-2003- & Cropland & $\begin{array}{l}\text { Cropland } \\
\text { conversion }\end{array}$ & 11,115 & $\begin{array}{l}\text { Acquisition and } \\
\text { conversion of } \\
\text { agricultural } \\
\text { land }\end{array}$ \\
\hline Americas & $\begin{array}{l}\text { Guatemala } \\
(55)\end{array}$ & $\begin{array}{l}\text { Commercial } \\
\text { (World Land } \\
\text { Trust) }\end{array}$ & ongoing & $\begin{array}{l}\text { Mangrove, } \\
\text { Flooded } \\
\text { Forest, } \\
\text { Mountain } \\
\text { Forest }\end{array}$ & $\begin{array}{l}\text { Laguna Grande } \\
\text { Sarstun } \\
\text { Reserve }\end{array}$ & 24,700 & $\begin{array}{l}\text { Acquisition, } \\
\text { management, } \\
\text { and fund } \\
\text { management }\end{array}$ \\
\hline
\end{tabular}


$\underline{\text { Table }} \underline{\mathrm{S} 3}$.

Assumed acquisition cost of protected areas in different regions (50)

\begin{tabular}{|l|l|}
\hline Region & Acquisition cost per $\mathbf{~ k m}^{2}$ in USD \\
\hline Asia & 2,293 \\
\hline CIS & 899 \\
\hline Latin America/Caribbean & 1,144 \\
\hline North Africa / Middle East & 1,259 \\
\hline Pacific & 17,395 \\
\hline Sub-Saharan Africa & 1,535 \\
\hline
\end{tabular}




\section{Supplementary References}

1. C. R. Margules, R. L. Pressey, Systematic conservation planning. Nature. 405, 243-253 (2000).

2. T. M. Brooks, R. A. Mittermeier, G. A. B. da Fonseca, J. Gerlach, M. Hoffmann, J. F. Lamoreux, C. G. Mittermeier, J. D. Pilgrim, A. S. L. Rodrigues, Global Biodiversity Conservation Priorities. Science. 313, 58-61 (2006).

3. K. J. Gaston, Global patterns in biodiversity. Nature. 405, 220-227 (2000).

4. Alliance for Zero Extinction, Global AZE map (2018).

5. J. M. Heberling, J. T. Miller, D. Noesgaard, S. B. Weingart, D. Schigel, Data integration enables global biodiversity synthesis. Proc Natl Acad Sci USA. 118, e2018093118 (2021).

6. A. C. Hughes, M. C. Orr, K. Ma, M. J. Costello, J. Waller, P. Provoost, Q. Yang, C. Zhu, H. Qiao, Sampling biases shape our view of the natural world. Ecography. 44, 1259-1269 (2021).

7. A. C. Hughes, H. Qiao, M. C. Orr, Extinction Targets Are Not SMART (Specific, Measurable, Ambitious, Realistic, and Time Bound). BioScience. 71, 115-118 (2021).

8. A. C. Hughes, M. C. Orr, Q. Yang, H. Qiao, Global Ecol Biogeogr, 8, 1375-1388 (2021).

9. K. S. Andam, P. J. Ferraro, A. Pfaff, G. A. Sanchez-Azofeifa, J. A. Robalino, Measuring the effectiveness of protected area networks in reducing deforestation. Proceedings of the National Academy of Sciences. 105, 16089-16094 (2008).

10. A. C. Hughes, Have Indo-Malaysian forests reached the end of the road? Biological Conservation. 223, 129-137 (2018).

11. E. M. O. Silveira, V. C. Radeloff, S. Martinuzzi, G. J. Martínez Pastur, L. O. Rivera, N. Politi, L. Lizarraga, L. S. Farwell, P. R. Elsen, A. M. Pidgeon, Spatio-temporal remotely sensed indices identify hotspots of biodiversity conservation concern. Remote Sensing of Environment. 258, 112368 (2021).

12. Population Density. WorldPop, (available at https://www.worldpop.org/project/categories?id=18).

13. P. Soille, A. Burger, D. De Marchi, P. Kempeneers, D. Rodriguez, V. Syrris, V. Vasilev, A versatile data-intensive computing platform for information retrieval from big geospatial data. Future Generation Computer Systems. 81, 30-40 (2018).

14. J. R. Meijer, M. A. J. Huijbregts, K. C. G. J. Schotten, A. M. Schipper, Global patterns of current and future road infrastructure. Environ. Res. Lett. 13, 064006 (2018).

15. World Food Programme (WFP), Global Railways (2017), (available at https://geonode.wfp.org/layers/geonode:wld_trs_railways_wfp/fp\#more). 
16. NASA EarthData, Night Lights 2020 Map. LAADS DAAC (2020), (available at https://ladsweb.modaps.eosdis.nasa.gov/missions-and-measurements/sciencedomain/nighttime-lights/).

17. P. G. Teluguntla, P. S. Thenkabail, J. N. Xiong, M. K. Gumma, C. Giri, C. Milesi, M. Ozdogan, R. Congalton, J. Tilton, T. T. Sankey, R. Massey, A. Phalke, K. Yadav, in Land resources: monitoring, modelling, and mapping (Taylor \& Francis, Boca Raton, Florida, 2015; http://pubs.er.usgs.gov/publication/70117684).

18. O. Venter, E. W. Sanderson, A. Magrach, J. R. Allan, J. Beher, K. R. Jones, H. P. Possingham, W. F. Laurance, P. Wood, B. M. Fekete, M. A. Levy, J. E. M. Watson, Global terrestrial Human Footprint maps for 1993 and 2009. Sci Data. 3, 160067 (2016).

19. P. Lujala, J. Ketil Rod, N. Thieme, Fighting over Oil: Introducing a New Dataset. Conflict Management and Peace Science. 24, 239-256 (2007).

20. J. Blossom, Global Oil Pipelines (2009).

http://worldmap.harvard.edu/data/geonode:global_oil_pipelines_7z9

21. Scientific Data Curation Team, Metadata record for: GOODD, a global dataset of more than 38,000 georeferenced dams (2020), p. 5796 Bytes, , doi:10.6084/M9.FIGSHARE.10538486.

22. A. C. Hughes, Understanding and minimizing environmental impacts of the Belt and Road Initiative. Conservation Biology. 33, 883-894 (2019).

23. E. W. Sanderson, K. H. Redford, A. Vedder, P. B. Coppolillo, S. E. Ward, A conceptual model for conservation planning based on landscape species requirements. Landscape and Urban Planning. 58, 41-56 (2002).

24. Copernicus Global Land Service. Copernicus, (available at https://land.copernicus.vgt.vito.be/PDF/portal/Application.html\#Home).

25. B. Xu, T. Park, K. Yan, C. Chen, Y. Zeng, W. Song, G. Yin, J. Li, Q. Liu, Y. Knyazikhin, R. B. Myneni, Analysis of Global LAI/FPAR Products from VIIRS and MODIS Sensors for Spatio-Temporal Consistency and Uncertainty from 2012-2016. Forests. 9, 73 (2018).

26. Y. Wang, R. Li, J. Hu, X. Wang, C. Kabeja, Q. Min, Y. Wang, Evaluations of MODIS and microwave based satellite evapotranspiration products under varied cloud conditions over East Asia forests. Remote Sensing of Environment. 264, 112606 (2021).

27. N. C. Coops, S. P. Kearney, D. K. Bolton, V. C. Radeloff, Remotely-sensed productivity clusters capture global biodiversity patterns. Sci Rep. 8, 16261 (2018).

28. E. Dinerstein, D. Olson, A. Joshi, C. Vynne, N. D. Burgess, E. Wikramanayake, N. Hahn, S. Palminteri, P. Hedao, R. Noss, M. Hansen, H. Locke, E. C. Ellis, B. Jones, C. V. Barber, R. Hayes, C. Kormos, V. Martin, E. Crist, W. Sechrest, L. Price, J. E. M. Baillie, D. Weeden, K. Suckling, C. Davis, N. Sizer, R. Moore, D. Thau, T. Birch, P. Potapov, S. Turubanova, A. Tyukavina, N. de Souza, L. Pintea, J. C. Brito, O. A. Llewellyn, A. G. 
Miller, A. Patzelt, S. A. Ghazanfar, J. Timberlake, H. Klöser, Y. Shennan-Farpón, R. Kindt, J.-P. B. Lillesø, P. van Breugel, L. Graudal, M. Voge, K. F. Al-Shammari, M. Saleem, An Ecoregion-Based Approach to Protecting Half the Terrestrial Realm. BioScience. 67, 534545 (2017).

29. Copernicus Global Land Operations "Vegetation and Energy" "CGLOPS-1" Framework Service Contract N 199494 (JRC).

30. M.-N. Tuanmu, W. Jetz, A global, remote sensing-based characterization of terrestrial habitat heterogeneity for biodiversity and ecosystem modelling: Global habitat heterogeneity. Global Ecology and Biogeography. 24, 1329-1339 (2015).

31. M. L. Hobi, M. Dubinin, C. H. Graham, N. C. Coops, M. K. Clayton, A. M. Pidgeon, V. C. Radeloff, A comparison of Dynamic Habitat Indices derived from different MODIS products as predictors of avian species richness. Remote Sensing of Environment. 195, 142152 (2017).

32. E. M. O. Silveira, V. C. Radeloff, S. Martinuzzi, G. J. Martínez Pastur, L. O. Rivera, N. Politi, L. Lizarraga, L. S. Farwell, P. R. Elsen, A. M. Pidgeon, Spatio-temporal remotely sensed indices identify hotspots of biodiversity conservation concern. Remote Sensing of Environment. 258, 112368 (2021).

33. D. Yamazaki, D. Ikeshima, R. Tawatari, T. Yamaguchi, F. O’Loughlin, J. C. Neal, C. C. Sampson, S. Kanae, P. D. Bates, A high-accuracy map of global terrain elevations: Accurate Global Terrain Elevation map. Geophys. Res. Lett. 44, 5844-5853 (2017).

34. G. T., R.-C. R.M., V. L.V., H. M., W. F., H. E., H. N., M. D., Tropical and Subtropical Wetlands Distribution version 2, , doi:10.17528/cifor/data.00058.

35. T. W. Crowther, H. B. Glick, K. R. Covey, C. Bettigole, D. S. Maynard, S. M. Thomas, J. R. Smith, G. Hintler, M. C. Duguid, G. Amatulli, M.-N. Tuanmu, W. Jetz, C. Salas, C. Stam, D. Piotto, R. Tavani, S. Green, G. Bruce, S. J. Williams, S. K. Wiser, M. O. Huber, G. M. Hengeveld, G.-J. Nabuurs, E. Tikhonova, P. Borchardt, C.-F. Li, L. W. Powrie, M. Fischer, A. Hemp, J. Homeier, P. Cho, A. C. Vibrans, P. M. Umunay, S. L. Piao, C. W. Rowe, M. S. Ashton, P. R. Crane, M. A. Bradford, Mapping tree density at a global scale. Nature. 525, 201-205 (2015).

36. A. C. Hughes, Understanding the drivers of Southeast Asian biodiversity loss. Ecosphere. 8, e01624 (2017).

37. X.-P. Song, M. C. Hansen, S. V. Stehman, P. V. Potapov, A. Tyukavina, E. F. Vermote, J. R. Townshend, Global land change from 1982 to 2016. Nature. 560, 639-643 (2018).

38. UNEP-WCMC and IUCN, Protected Planet: The World Database on Protected Areas (WDPA) and World Database on Other Effective Area-based Conservation Measures (WDOECM)) [Online] (2021), (available at www.protectedplanet.net).

39. World Bank, Debt Service Payments Projections: What do we measure (n.d.), (available at https://databank.worldbank.org/data/download/site- 
content/Debt $\% 20$ Service $\% 20$ Payments $\% 20$ Projections-\%20What $\% 20$ do $\% 20$ we $\% 20$ measu re.pdf).

40. World Bank, COVID 19: Debt Service Suspension Initiative. World Bank (2020), (available at https://www.worldbank.org/en/topic/debt/brief/covid-19-debt-service-suspensioninitiative).

41. IMF, Questions and Answers on Sovereign Debt Issues. IMF (2021), (available at https://www.imf.org/en/About/FAQ/sovereign-debt).

42. IMF, Debt Sustainability Analysis. World Bank, (available at https://www.worldbank.org/en/programs/debt-toolkit/dsa).

43. I. D. Craigie, R. L. Pressey, "Towards a better understanding of protected-area management costs” (preprint, PeerJ Preprints, 2018), , doi:10.7287/peerj.preprints.26576v1.

44. A. Waldron, V. Adams, J. Allan, A. Arnell, et.al., "Protecting 30\% of the planet for nature: costs, benefits and economic implications (Waldron Report 30 by 30)" (Cambridge University, Cambridge, 2020), (available at https://www.conservation.cam.ac.uk/files/waldron_report_30_by_30_publish.pdf).

45. J. J. Bohorquez, A. Dvarskas, E. K. Pikitch, Filling the Data Gap - A Pressing Need for Advancing MPA Sustainable Finance. Front. Mar. Sci. 6, 45 (2019).

46. D. P. McCarthy, P. F. Donald, J. P. W. Scharlemann, G. M. Buchanan, A. Balmford, J. M. H. Green, L. A. Bennun, N. D. Burgess, L. D. C. Fishpool, S. T. Garnett, D. L. Leonard, R. F. Maloney, P. Morling, H. M. Schaefer, A. Symes, D. A. Wiedenfeld, S. H. M. Butchart, Financial Costs of Meeting Global Biodiversity Conservation Targets: Current Spending and Unmet Needs. Science. 338, 946-949 (2012).

47. S. Gantioler, M. Rayment, S. Bassi, M. Kettunen, A. McConville, R. Landgrebe, H. Gerdes, P. ten Brink, "Costs and Socio-Economic Benefits associated with the Natura 2000 Network" (Final Report to the European Commission, Institute for European Environmental Policy / GHK / Ecologic, Brussels, 2010), (available at https://ec.europa.eu/environment/nature/natura2000/financing/docs/natura2000_costs_benef its.pdf).

48. S. R. Frazee, R. M. Cowling, R. L. Pressey, J. K. Turpie, N. Lindenberg, Estimating the costs of conserving a biodiversity hotspot: a case-study of the Cape Floristic Region, South Africa. Biological Conservation. 112, 275-290 (2003).

49. A. N. James, M. J. B. Green, J. R. Paine, The global review of protected area budgets and staff (World Conservation Press, Cambridge, 1999), WCMC biodiversity series.

50. P. Shabecoff, Bolivia to Protect Lands in Swap for Lower Debt. The New York Times (1987), p. 2.

51. World Land Trust, Tanzania's Coastal Forests: 49,000+ acres saved as WLT supporters help exceed appeal target within weeks. World Land Trust (2021), (available at 
https://www.worldlandtrust.org/news/2021/05/tanzanias-coastal-forests-appeal-targetexceeded/).

52. ICFC, Bolivia: Conserving the Blue-throated Macaw and the Beni Savanna. International Conservation Fund of Canada (n.d.), (available at https://icfcanada.org/ourprojects/projects/barba_azul).

53. Nature \& Culture International, Conservation of Endangered Forests in Sierra de Alamos, Mexico. Nature \& Culture International (n.d.), (available at http://www.naturalezaycultura.org/concept/htm/mexico/mexico.htm).

54. China Ministry of Foreign Affairs, Building a Shared Future for All Life on Earth: China in Action (20AD), (available at https://www.fmprc.gov.cn/mfa_eng/wjdt_665385/2649_665393/t1816598.shtml).

55. World Land Trust, Laguna Grande Sarstún Reserve. World Land Trust (n.d.), (available at https://www.worldlandtrust.org/tabs/laguna-grande-sarstun/). 


\section{Supplementary Files}

This is a list of supplementary files associated with this preprint. Click to download.

- Datas1.xlsx

- DataS2.xlsx

- DataS5.xlsx

- Datas3.xIsx

- DataS6.xlsx

- Datas4.xlsx 